\title{
Here Be Dragons Mapping an Ethnography of Global Danger
}

\author{
by Ruben Andersson
}

\begin{abstract}
For a brief post-Cold War moment, it seemed as if global division would yield to connectivity as marginal regions would be rewired into the world economy. Instead, the post-9/11 years have seen the spread of ever-larger "no-go zones," seen as constituting a danger especially to Western states and citizens. Contact points are reduced as aid workers withdraw, military operations are conducted from above, and few visitors, reporters, or researchers dare venture beyond the new red lines. Casting an eye on this development while building on anthropology's critical security agenda, this article draws an ethnographic map of "global danger" by showing how perceived transnational threatsterrorism, drugs, and displacement-are conjured, bundled, and relegated to world margins, from the sub-Saharan Sahel to the Afghanistan-Pakistan borderlands. Drawing on fieldwork conducted in Mali, it shows how a relationship by remote control has developed as Western interveners seek to overcome a fundamental dilemma: their deep concern with threats emanating from the danger zone set against their aversion toward entering it. As ambivalent sites of distance and engagement, I argue, such zones are becoming invested with old fantasies of remoteness and otherness, simultaneously kept at arm's length and unevenly incorporated into a world economy of risk.
\end{abstract}

Planning for fieldwork in conflict-hit Mali in 2014 from my then-London home, I clicked through Google Maps to search for Timbuktu. In a split second, I got car directions for that one-time epitome of remoteness - 3 days and 12 hours via the N-6 on a route that "has tolls," "includes a ferry," and "crosses through multiple countries," as the map helpfully informed me. Yet that bright blue route curling down through Europe and Africa was but a thin, even illusory thread of connectivity. Timbuktu and northern Mali — an area that, only a few years ago, hosted festival-goers and researchers eager to tap into Mali's rich culture - was by this time off-limits to most Western visitors; it had become yet another reblanked part of the world map at a time of rampant globalization.

Hic sunt dracones. Those medieval maps may not have spelled out "here be dragons," as we tend to think, yet they were often adorned with fantastical creatures, dragons, and exotic beasts that served as flourishes or as indicators of the limits of our knowledge (Van Duzer 2013). Now the beasts are back, or so we hear on the news: vague threats are lurking in far-flung corners of our maps, areas where the inhabitants of the Western world no longer dare venture. Syria and Iraq's embattled border zones, Somalia and Pakistan's tribal areas, Afghanistan's hinterland, and the northern reaches of the sub-Saharan Sahel are all regions harboring a litany of con-

Ruben Andersson is an Associate Professor at the Department of International Development at the University of Oxford (Queen Elizabeth House, 3 Mansfield Road, Oxford OX1 3TB, United Kingdom [ruben. andersson@qeh.ox.ac.uk]). This paper was submitted 21 VII 15, accepted 4 XI 15, and electronically published 14 XI 16. temporary fears. Terror and drug-running, disease and disaster, conflict and displacement: these dangers fester on the margins of our maps, vague yet distant to Western publics, forever at a remove until they blip by on the newscasts, temporarily bringing news of distant atrocities and random tragedies.

For most Western citizens, these new no-go zones are not of great concern; they are remote and rarely any of their business. Not so, however, for anthropologists, as our discipline has long been intimately tied to the exploration of global margins. In this article, starting with my own anthropological dilemma at the edge of the danger zone of northern Mali, I will give an account — at times personal, at times political — of shifts in global insecurity and what role our discipline may have in mapping and interrogating these shifts as we critically draw on our disciplinary heritage.

The "danger question" has become increasingly acute for anthropology as the discipline has had to face up to insecurity on both practical and theoretical fronts in recent years. ${ }^{1}$ In Fieldwork under Fire, Nordstrom and Robben (1995) engaged with dilemmas that have lingered on our ethnographic field of vision ever since: how to research and write about violence tearing through communities with which we are deeply familiar, while adapting our methods and ethics to deal with situations of conflict and danger. Their volume moreover high-

1. A note on terminology: "risk" here refers to the projected impact and likelihood of a threat, "danger" or "insecurity" designates the state above an acceptable risk threshold, and "fear" is often the psychological and emotional corollary of such danger. 
lighted the growing interest among anthropologists in stepping onto "dangerous fields" (Kovats-Bernat 2002) since the 1990s (e.g., Besteman 1999; Daniel 1996; Sluka 2000). The increasingly serious engagement with violence, (in)security, and risk is also evident in landmark ethnographies set within the West, whether in violent urban areas (Bourgois 2003; Feldman 1991) or inside the powerful security apparatus itself (e.g., Lutz 2001). In the post-9/11 era, with its various iterations of the "war on terror," this interest has flourished (Fassin 2013; Gusterson 2004; Masco 2014; Whitehead and Finnström 2013). As evident from Maguire, Frois, and Zurawski's (2014) volume The Anthropology of Security, building on Goldstein's (2010) call for a "critical security anthropology," anthropologists have started to take (in)security seriously as an object of study in its own right. As a result, they may no longer all leave a war zone as journalists enter, as Malkki (1997:93) once put it-indeed, some have even gone as far as advising militaries in the field, reinvigorating a much older cooptation of our working methods by those in power (Price 2011).

As the last sentence suggests, the problems with this move onto "dangerous fields" of (in)security are manifold: ethical, methodological, and political. Politically, our academic endeavors are symptomatic of security's broader "colonization" of ever-larger parts of social life, as Goldstein (2010:488) and Maguire, Frois, and Zurawski (2014) have noted. Indeed, "security" is now everywhere. In a compelling study of the post-9/11 US “counterterror state," Masco (2014) notes how a catastrophic official orientation toward unlimited future (terrorist) threats has seen security practices extended into the global arena and novel fields, ranging from disease control to development aid and academia, where solid funding streams have emerged on "border security," "biosecurity," "cybersecurity," and "violent radicalization." At this post-Cold War juncture, characterized by vicious cycles of ever-expanding security apparatuses and the constant generation of novel threats (Masco 2014), one key task for anthropology is to denaturalize security, calling into question how it is summoned, how it is put to work, and how it is given meaning in specific settings, as Goldstein (2010) has insisted. Indeed, anthropologists are already providing the larger fields occupying the security terrain - international relations, sociology, criminology, and "security studies" in all its shapes and sizes - with a healthy dose of caution against putative "global" claims on the nature of security as well as with methodological inspiration as security scholars shift focus from discourse to praxis (Bigo 2014). At this productive interface, Goldstein (2010), Maguire, Frois, and Zurawski (2014), and Fassin (2013) have all rightly urged anthropologists to be attentive to "local expressions and meanings" 2 as the content and form of security shift across the world, from the terrorist focus of the post-9/11 United States to the urban policing of Fassin's

2. Citation from the Cultural Anthropology online special on security, http://www.culanth.org/curated_collections/14-security/discussions/13 -security-a-conversation-with-the-authors (accessed July 21, 2015).
(2013) French field site and the neoliberal unraveling in Goldstein's (2010) Bolivia. In this grounded manner, ethnographers can help unpack the "black box" of security, an urgent task indeed in our "dark times" (Fassin 2011) of deepening counterterror measures, taller border barriers, and aggressive innercity policing.

Yet problems loom on practical fronts once we step out of the West and enter the "red zones" of conflict, crime, and instability of the kind I was preparing for in Mali in 2014, which I will refer to in this article as the new global "danger zones." ${ }^{3}$ In a critical historical note, Kovats-Bernat (2002:211) points out how the "stability in the ethnographic field" once guaranteed by colonial power no longer holds. Indeed, in an era of rampant insecurity and fragile postcolonial states, our quest for knowledge of the insecure Other is becoming intimately tied up with the insecurity of the anthropological Self.

Starting with this personal and political predicament, I will go down a complementary path to the localized route traced by Goldstein, Fassin, and others in focusing on how global forms of insecurity and danger are conjured, mapped, and intervened upon by Western states, which remain the main funders and instigators of international intervention. As Masco recently put it, delineating such a field of inquiry, "Across a wide range of security concerns from climate change to infectious disease new modes of surveillance are offering a real time portrait of specific threats that transcend state borders. This technological expansion in how danger is constituted, how it is visualized, and how it is tracked in everyday life has the potential to enable a new kind of planetary security discourse."4

What follows, then, is an ethnographic mapping exercise that traces the pathways and clusters of increasingly global dangers. Although such an ethnographic effort will, to some extent, have to be global, too (Burawoy 2000), in the material that follows, the focus will be on the sub-Saharan Sahel, and Mali in particular, as well as this region's linkages in terms of risk and danger with control centers and capitals elsewhere.

Even in its regionally circumscribed version, such an ethnography of global danger does present several anthropological dangers: of context, of voice, and of method. As anthropologists branch out methodologically to deal with conflict "at a distance" (Robben 2010), our approaches may uneasily come to mirror those of the interveners themselves - the dronewielding warriors, the headquartered aid worker managers, and the bunkered embassy bureaucrats. However, I believe this is one danger we should be willing to face, and not just because anthropological insights will otherwise remain marginalized in larger academic and political debates, as Robben (2010:20-21) shows was the case with Iraq. In fact, the su-

3. The link between Western, urban high-risk areas and foreign, distant danger zones cannot be elaborated on here for lack of space; compare Lianos and Douglas 2000.

4. Masco in conversation, http://www.culanth.org/curated_collections /14-security/discussions/13-security-a-conversation-with-the-authors (accessed July 21, 2015). 
perficiality and "thinness" of contemporary international interventions itself presents an intriguing ethnographic challenge, as Feldman (2012:18-19) has asserted in a rather different context. Our methodological limitations link us into this larger field of intervention; they constitute one more window onto a distinctly global process of distance making and danger.

I will argue, then, that anthropologists may be very well placed not only to embark on studies of the microphysics of (in)security - its intricate local workings and manifestations but that we may also venture into researching the very globality of insecurity and danger. I will suggest that one way of doing so, complementing Masco's (2014) archival approach, is to mine a rather traditional ethnographic vein to its point of impossibility. In the exotic fieldwork tradition, anthropologists are canaries in the academic coal mine, poised at the very entrance to the insecure world "out there." An ethnography of global danger, then, may start with reflexively accounting for our own fears and vulnerabilities at this threshold, as Kovats-Bernat (2002: 217) has also suggested. Here, our individual sense of danger, rather than being a mere obstacle, may serve as a jumping-off point as we survey the production of insecurity and novel "security-scapes" (Gusterson 2004) in crisis-hit areas.

However, this reflexive turn is only the start. As will be clear in the preamble below, concerned with my fieldwork on Mali's conflict, anthropologists' ambivalent relation to the dangerous field is but one small symptom of a much larger withdrawal by international actors from the danger zone. Section one traces this trend toward growing global distance, showing how a new relationship by remote control has developed between (especially Western) interveners and intervened-upon populations. Next, section two argues that this reorganization is itself indicative of a larger sociopolitical shift as the relationship between the richest and poorest parts of the world is becoming reframed through a set of clustered threats. The third section, finally, looks at how danger and threat scenarios are also increasingly mobilized as a local resource - that is, by institutions and inhabitants of the danger zone- often with considerable ambivalence and with counterproductive consequences.

How may we understand the growing geographical divides between "red" and "green" zones today? In the conclusion, I will build on the literature on global risk to suggest that the increasing remoteness of red zones should not blind us to their function within a world economy of risk and insecurity. Anthropologists will have much to contribute to the understanding of this globalized role as we critically draw on our disciplinary heritage of studying faraway places. Authors such as Harms, Hussain, and Shneiderman (2014), McDougall and Scheele (2012), Piot (1999), Saxer (2016), and Tsing (1993) have in recent years radically reframed the old anthropological trope of remoteness, showing supposedly remote areas to be crisscrossed by intricate pathways linking them to global and national orders. This article will show how danger may serve as precisely such a pathway; yet it is a pathway of a particular sort. Danger is double-edged: it separates yet draws us near. As interveners and politicians seek to draw a distance between the West and the new danger zones, the latter come to exercise a peculiar power over what Trouillot (2003) has called the "Western geography of imagination." As risk and danger are being remapped and reimagined at a time of supposed global connectivity, Western interveners, citizens, and anthropologists increasingly fear entering yet grow fascinated with the distant danger zone, with far-reaching consequences that we are only just beginning to understand.

\section{Preamble: Ethnography and the Withdrawal from Danger}

"The one thing that we can be certain about this year, in a highly uncertain world, is that there is no longer any such thing as far away." These were the words of an executive with Control Risk, a UK-based private security company, as he launched his company's Risk Map for 2015 with an online video. Yet the map itself, set behind the executive, told a different story: on it, large swathes of the world were covered in aggressive shades of red, indicating high or extreme risks, rendering the world as a patchwork of safe, rich areas on the one hand and impoverished, insecure no-go zones on the other. $^{5}$

While the Risk Map targets large corporations, including those seeking to enter "frontier markets" in the red areas, similar cartographic representations abound elsewhere, too. During my research, I have come across the interactive maps used by security companies to track risks to their clients; visual depictions of blood-red danger zones in the media; sketched cartographies of risk in Western foreign ministries; and the familiar maps of official travel advice (fig. 1). In this world of red and green zones, the trend is clear: US no-go advice covered 12 African countries in 1996; by 2013, that figure was 18 . The UK Foreign Office had 13 countries or parts of countries on its global no-go list in 1997; in 2012, that figure was 40, again with many new entries for Africa. Meanwhile, the number of Western victims of terror attacks in regions such as Africa in fact remains very low: only 15 of the 1,005 Americans killed in terrorist acts worldwide between 2004 and 2013 were killed in acts that took place on the continent, for instance. ${ }^{6}$ Yet the media impact of any attack, as seen from Kenya to Tunisia, far surpasses the actual numbers, triggering swift changes in official travel advice and usually the exit of Westerners. In this politicized landscape of risk assessment, large areas of our maps are being painted in deep

5. Video (Top 5 for 2015) available at https://riskmap.controlrisks .com (accessed July 21, 2015).

6. Public Radio International has crunched the US figures on no-go zones and fatalities: http://www.pri.org/stories/2014-07-07/us-travel-warnings -out-africa-more-strategy-summer-read (accessed July 21, 2015). UK travel advice data compiled from national archive material is available at http:// webarchive.nationalarchives.gov.uk/*/http:/www.fco.gov.uk/ (accessed July 21, 2015). 


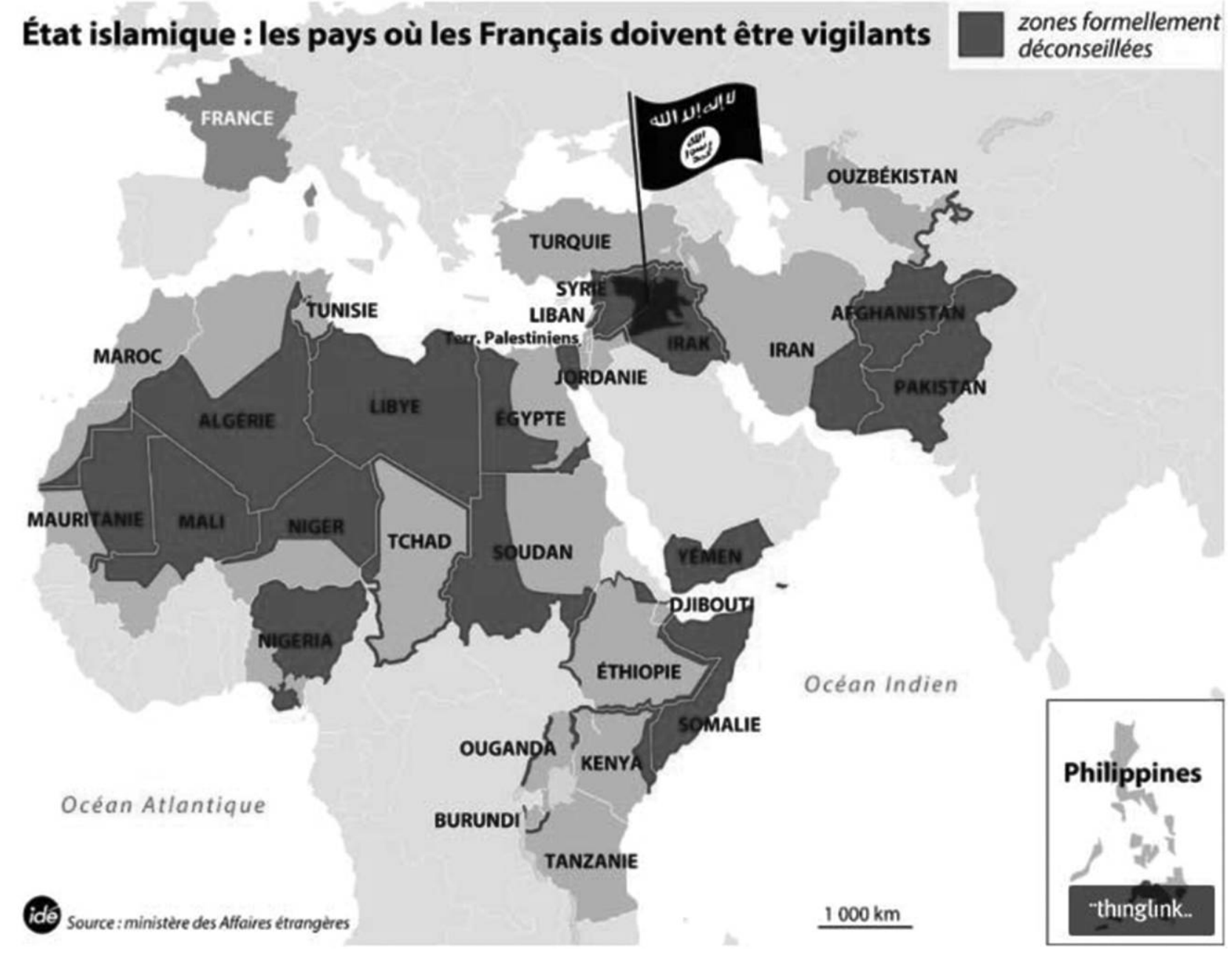

Figure 1. French media depiction of the global presence of ISIS/ISIL/Daesh. A color version of this figure is available online.

shades of red, turning them into zones that we enter, if at all, at our own risk and peril (fig. 2).

Mali, the case study in this article, has come to be emblematic of the global mapping of danger, not least as regards the speed by which it descended into the "deep red" category of extreme risk. For some time, this landlocked country was a haven of peace and democracy in West Africa. Moreover, the country's "desert blues" festivals, its blue-clad Tuareg (Tamachek) nomads, and its deep historical heritage helped place it on a cultural map of interest to tourists and anthropologists alike (see Soares 2012 for a critical assessment). Yet all was not right. By the late 2000s, travel advice was painting northern Mali in a deep red owing to the growing jihadist presence. Notravel advice meant no insurance, and so budget flights from Europe were cut, festivals cancelled, and contact points severed. By early 2012, a northern Tuareg rebellion - the fourth since Mali's independence from France in the 1960s - had begun, followed by a coup d'état in Bamako. As northern Mali was taken over by a combination of Tuareg separatists and jihadist factions that spring, the simplistic donor notion of
Mali as an "aid darling" (Bergamaschi 2014) was swiftly being transformed into something else entirely, as security analysts started referring to the country as "Africa's Afghanistan" (Solomon 2013). As the jihadists eventually began pushing south, the French responded by launching a military operation in January 2013, retaking northern towns. Operation Serval was eventually followed by an African peace force, integrated into the United Nations (UN) Multidimensional Integrated Stabilization Mission in Mali (MINUSMA) by mid-2013.

It was in this context that I had come to Mali in May 2014 for fieldwork on international intervention, building on earlier research in 2010-2011 on migration and border controls. Descending onto Bamako's Senou airport, one change from the prewar years was already in evidence: on the tarmac stood seven black UN military planes, lined up in waiting for the cargo and personnel making their way to Mali's war-scarred north. Inside the airport terminal, a Western woman scuttled between the police booths, overseeing Malian officers grappling with newly installed biometric equipment. Police aimed infrared pistols at us, screening for Ebola. Mali, it was clear 

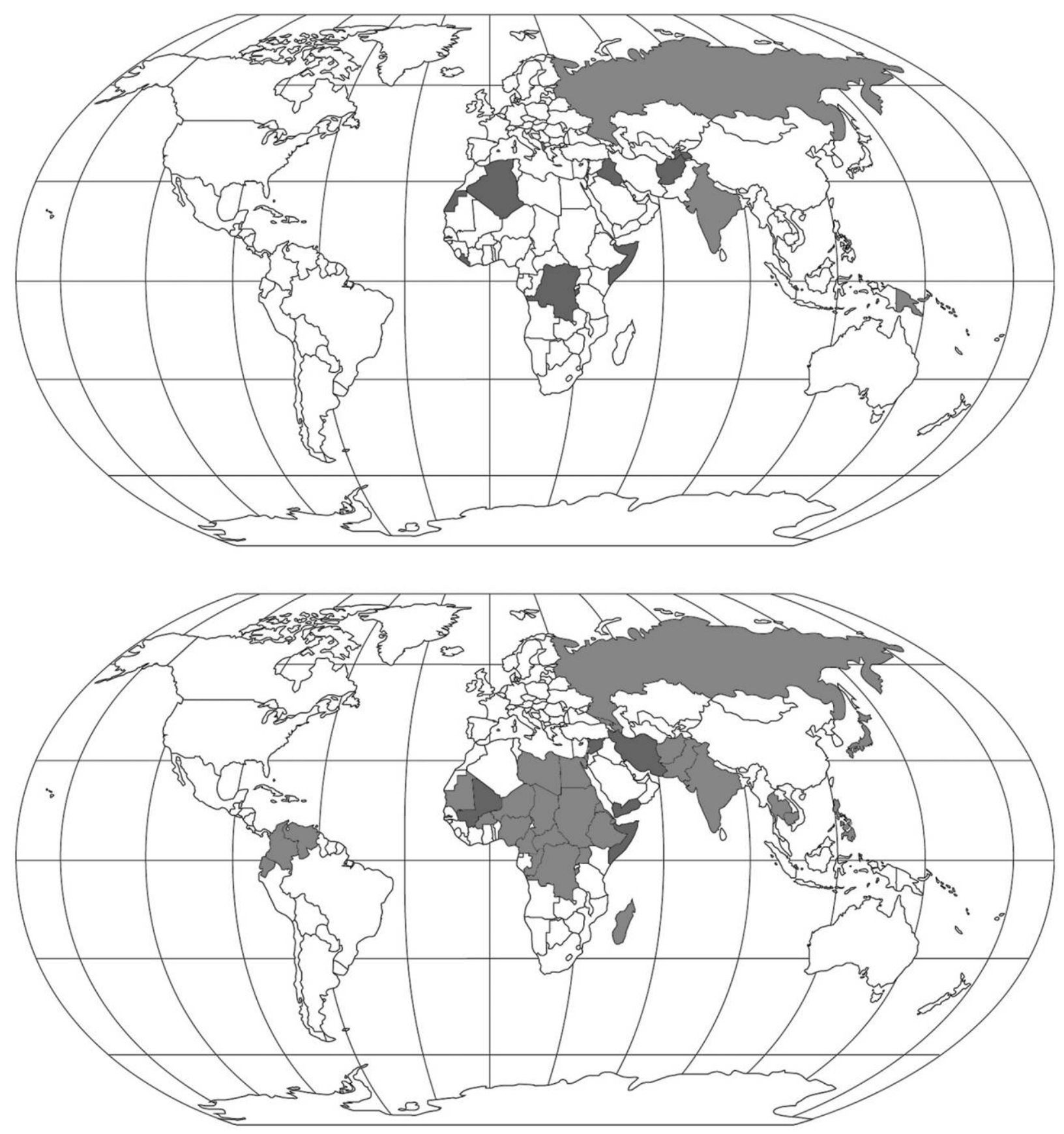

Figure 2. UK travel advice, 1997 (top) versus 2012 (bottom). Countries with no-travel advice are shown in dark gray; no-travel advice for part(s) of country in light gray. A color version of this figure is available online.

after only a few minutes back on its soil, was now a country under international tutelage, its security assured by foreign soldiers and its borders controlled by Western devices and expertise. It was also a country marked by an edginess that I had not experienced on previous visits, I thought, as I finally found a taxi in a remote corner of the airport parking lot. As we bumped our way down empty streets toward central Ba- mako, I kept looking over my shoulder, as if on guard against an unlikely ambush.

Studying the international response to the Mali conflict, as well as its interaction with longer-running interventions targeting the chronic livelihoods crises of the Sahel, as I had set out to do, was to prove a challenge. As I had prepared for fieldwork in early 2014, the question of whether I would ac- 
tually be able to visit the places of concern to my research had become increasingly acute. Going north, as travel advice, the newscasts, and my university kept telling me, meant exposure to unseen dangers. Along with being home to an array of rebel groups, the region presumably still harbored al Qaeda affiliates who threatened kidnap and targeted attacks. The risk was such that, as I interviewed Control Risk officers in London, they acknowledged they had had to turn down a project in the region owing to "internal risk" to staff. If companies capitalizing on global insecurity would not go themselves, then who would? Was it not cowardly to stay away, though, and did not locals face much larger dangers? There I sat, in my London office, scheming and tallying and anxiously eyeing the news as "the field" receded ever further from full ethnographic reach.

Now that I had finally arrived, I would only stay in the capital; yet even this highly circumscribed visit had not been all that easy, despite Bamako being some 1,000 km away from the northern "front line." While the north was still a no-go zone, colored red on UK travel advice maps, the capital had "none but essential" advice because of the kidnap and terror threat. As a consequence, my university had asked me to complete a drawn-out risk assessment, fill in long forms, attend security meetings, and read up on safe procedures. I had to provide the university's private security contractor with specific information to be used in case I were to be kidnapped, and I was given a security app through which I had to log every day as proof of life. My top-up kidnapping insurance mounted to $£ 1,000$ for a month, which was discounted, after some hard bargaining, to $£ 750$ as long as I did not leave the capital. With such rates and procedures, none but the most dedicated would even attempt to arrive in Mali, precisely at a time when the country was thirsting for renewed connections.

My predicament was far from unique. Other academics, journalists, humanitarians, and even soldiers and security contractors, such as the Control Risk officers, face the problem of no-go zones, although we rarely dwell publicly on our decisions about entering them. Yet the dilemma can no longer be ignored, because whole chunks of the contemporary world, from Mali to Pakistan and beyond, are rife with dangers - at least if we are to trust our employers, newspapers, insurance companies, and travel advice-wielding foreign ministries. As I spoke informally to academic colleagues working on Mali and the wider Sahel, I would sense the shift firsthand: researchers with long familiarity with the region were now staying away and finding other topics and destinations, in part owing to personal concerns and in part because universities may refuse to give the green light to their trips. The same also applied to me: as I e-mailed my university's security provider to tell them the mobile app served little purpose in Bamako, I still followed their advice of not leaving the capital.

Again, as is the case for other researchers, my apprehensions cannot be blamed on institutional straightjackets alone. Terrorist risk may be limited, statistically speaking, yet the specific insecurities besetting crisis zones such as northern

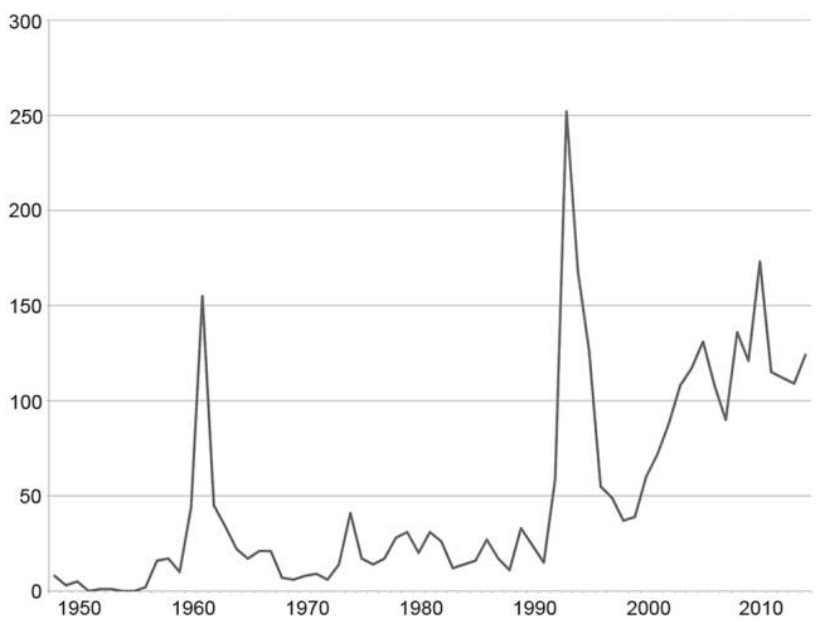

Figure 3. United Nations peacekeeping fatalities by year.

Mali still do remain real. Although the trend remains disputed, it is clear that armed groups increasingly see those who were once deemed neutral to conflict, such as reporters, aid workers, and peacekeepers, as fair game. The killing of journalists worldwide remains high, with 61 confirmed deaths in 2014; 155 aid workers were killed in 2013, according to one count, the highest figure for many years; and fatalities among peacekeepers are also rising, albeit still short of a spike in the early 1990s (fig. 3). In Mali, as in Syria and Libya, jihadist groups have come to see Western hostages as a propaganda tool and source of income owing to large ransom payments, thus racializing risk in troubling ways. ${ }^{7}$

Grappling with high-risk areas, as researchers are now explicitly doing (e.g., Sriram 2009), we have a range of options at our disposal, yet all of these options uneasily reflect the new global fault lines between safety and danger. As anthropologists, we may opt for "armchair anthropology redux," bolstered by new communications technology (Gusterson 1997) and our lingering field authority - that is, the experience of "having been there," to paraphrase Hannerz (2003). Alternatively, we may follow the freelance reporters skirting roadblocks and boldly set out as "ethnographic explorers," again reviving early anthropological approaches of engaging with the "dangerous Other." More pragmatically, we may engage in "ethnography by proxy," drawing on local collaborators, or start "fieldhopping," skirting the danger zone by visiting for short periods and restricting ourselves to relatively safe areas. These options, however combined, constitute pragmatic ways of retaining a hold on important research topics (Kovats-Bernat

7. Figures are from the Committee to Protect Journalists (https://www .cpj.org/killed/; accessed July 21, 2015); the Humanitarian Outcomes database (https://aidworkersecurity.org/incidents/report/summary; accessed July 21, 2015); and the UN Department of Peacekeeping Operations online database (http://www.un.org/en/peacekeeping/resources/statistics/fatalities.shtml; accessed July 21, 2015), respectively. 
2002; Hagberg and Körling 2014). Yet in their various tradeoffs with insecurity, they also indicate some of the points of friction, conflict, and ambivalence characteristic of a relationship between rich and poor that is increasingly framed by potential danger.

As for my own research, rather than persisting with gaining entry to Mali's northern danger zone, I decided to stay away. A cop-out, perhaps. But it is the cop-out deployed by an everlarger number of groups, including Western militaries, which, after all, are equipped to face the deadliest risks. My aim became to understand the remote-controlled interventions increasingly engaged in by the UN and Western powers at a time of supposed global connectivity. As a consequence, my field had to be reshaped around the means and sites used to draw distance toward and intervene in the danger zone. Traveling across an extended field site stretching from Western government ministries to UN mission headquarters, online visuals, and the aid world of Bamako, I started circling the danger zone, seeing it from above, scanning and mapping it somewhat like an anxious drone of the kind deployed by the US, UN, and France to monitor (or kill) distant threats.

Seeing the Mali conflict through this reflexive risk lens, I thus came to treat my own ethnographic predicament as symptomatic of a larger shift in the landscape of international intervention. For instance, the mere detail of the security app on my mobile, provided by a competitor to Control Risks, linked me to an institutional and globalized framing of specific dangers while also serving as a nagging reminder that I was somehow detached even from the rather safe Bamako confines of my study. Along with my insurance arrangements and fieldwork anxieties, the app illustrated how security risk was being mapped onto Mali in highly political ways, enabling some forms of connectivity - and some forms of risk-taking - while disabling others, just as was the case in other high-risk and conflict areas, from the Syria-Iraq axis to Somalia, Libya, and the "AfPak" (Afghanistan-Pakistan) borderlands. This geography of intervention will be the focus of the next section.

\section{Distance to Danger: A Relationship by Remote Control}

Since my last visit of 2010-2011, the international presence of Bamako had shifted radically. The only traveling toubabs, or white folk, who remained in the new Bamako were ragged adventurers of a familiar kind, including rough-hewn luckseekers from France and the odd trans-Saharan bikers. From the terrace of my guesthouse, I and the bikers observed a new generation of punters stream past each night: young Western humanitarian managers heading for the breezy rooftop bar; African mine-clearers with the UN Mine Action Service; freelance journalists, linen-clad and lanky; and African peacekeepers in uniform. "Peaceland," as Autesserre (2014) has called the self-contained world of UN missions, had descended on Bamako like an extraterrestrial ship unloading its cargo and personnel, and the capital's guesthouses had been repurposed to hold their spillover, throwing a lifeline to our Swiss host and her staff.

One night, I found one of Bamako's newcomers under the terrace fans. Monica was an administrator with the UN; staying in our guesthouse, she was about to be sent up to Mali's north. Such trips to far-flung danger zones had been her life for the better part of two decades; arriving in Mali, she had bumped into old colleagues from Kosovo. Monica's long experience should have prepared her for the dangers of Mali, yet there was something with this mission that unsettled her. "I don't feel calm here," she confided during one of the many nights when we spoke on the terrace. "This is the first time that I have felt vulnerable, and it's not as if it's my first mission. . . It was different in Congo; there the mission was well established. Here they are not in control; they are not prepared. I don't feel safe." To make matters worse, her grasp of French, Mali's old colonial language, was tenuous at best. "CNMA, what are they called?" she asked with a laugh, referring to the main Tuareg separatist faction, the MNLA, or the National Movement for the Liberation of Azawad (the name used by the separatists in northern Mali). "I could in theory have said no to this, but it's what I signed up for, it's a peacekeeping mission."

Monica's apprehensions were shared by many of the "expats" I interviewed in Bamako, including at the UN mission, UN agencies, Western embassies, and nongovernmental organizations (NGOs). ${ }^{8}$ To some extent, these doubts reflected political tensions around MINUSMA. In 2014, some troop-contributing countries had argued that this type of mission (authorized to use force and deployed in parallel to the French military operations) dangerously blurred the line with counterterrorism; meanwhile, among humanitarian agencies, the mission's integrated character was seen as adding to the risks to staff, because they were perceived as being under the same UN umbrella as the soldiers. However, by spring 2014, not many successful attacks against the internationals had taken place, or as one UN officer collating data on these told me, "Mali's not Afghanistan." That was sadly about to change. In late 2014, amid growing attacks on peacekeepers, one high-ranking UN official would despairingly tell me in New York: "There is no enemy any longer, and who is the target? We are." The "multi-dimensional integrated stabilization mission in Mali" had a long name that tried to hide the fact it was a peacekeeping mission with no peace to keep, hostage to elusive dangers lurking on the horizon.

As it set up shop across Mali in mid-2013, MINUSMA had geared its operations toward these yet-to-be-realized dangers. In the northern towns of Gao, Timbuktu, and Kidal, peacekeepers and civilian UN staff lurked behind high walls, from where - or so locals complained - they all too rarely emerged to keep the people safe from attacks by either rebels, stray

8. My Bamako and Dakar (regional headquarters) research has involved about 60 interviews with UN staff, aid workers, peacekeepers, and local associations. 
Islamists, or the Malian armed forces. Yet even in Bamako, 1,000 km away from Timbuktu, Monica and her colleagues labored at one remove from the locals. For its headquarters, MINUSMA had commandeered the five-star Hotel de l'Amitie in central Bamako. To Mali's government, the very decision to locate the mission HQ in the capital was a provocation, indicating the state's failure to manage its own affairs. To the $\mathrm{UN}$, however, the reason behind a Bamako base was simple: insecurity in the war-scarred north-that is, precisely the insecurity it was supposedly there to prevent. Amitié was off bounds to any locals behind its cement vehicle barriers, curls of razor wire, and tanks manned by armed blue helmets. Its pool, which on my last visit was a favored haunt of the local elite, now hosted restaurants serving up crisp pizzas to Danish soldiers and American political advisers. As UN staff drove up to the gates at lunchtime in their identical white four-wheel drives, they clogged up the busy road outside, frustrating local drivers, not least since everyone knew that the Malian government had to pay a large subsidy for housing MINUSMA in the hotel.

This bunkering was in itself indicative of a trend toward fortification since the 1990s, whether by the UN or by the United States in postinvasion Baghdad (Chandrasekaran 2006). As noted by a growing body of studies (e.g., Duffield 2010; Fast 2014; Andersson and Weigand 2015), such bunkering and buffering has increased the distance from local society in a dangerous spiral that risks generating novel dangers as contact points diminish and resentment stirs, as was to be the case in Mali in 2014.

As I walked Bamako's darkened alleyways at night, joining streetside grins (friendship groups) for tea or meeting with friends, it was soon becoming clear that the foreign interveners, recently welcomed as liberators, were no longer all that popular. The international party scene, the seemingly excessive pay, and talk of rising prostitution stirred resentment, but the main cause of anger was the impression that the UN was not providing security in the north.

Critique was voiced internally, too. In the words of one peacekeeper, MINUSMA was a "giant with a bloated head and clay feet," teetering precariously on the northern front lines as the bunkered headquarters of Bamako grew ever larger. Indeed, the north was mainly patrolled by African soldiers who performed this task without armored cars, with scant protection, and with little preparation for the dangers ahead. Unsurprisingly, they would also end up being the largest takers of casualties as attacks kept mounting. By February 2015, there were already 46 dead in the mission, and the number kept rising thereafter. Unlike 1990s missions, such as the UN Mission in Somalia (UNOSOM), which saw a fairly equal division of fatalities among Asian (44\%), African (22\%), and Western (34\%) peacekeepers, the mission in Mali has experienced a disproportionate number of African fatalities. Among the 46 fatalities in Mali, 5 were Asian and 41 were African, with 18 of these from a single country, Chad, whose soldiers manned both the French counterterror front line and the riskiest regions covered by MINUSMA. ${ }^{9}$ The "Africanization" of peacekeeping, held up as a goal in powerful quarters (Tardy and Wyss 2014), has here entailed a risk transfer away from well-prepared Western soldiers toward the ragtag brigades of the Africans, as European officers readily recognized in interviews.

A similar trend was besetting nonmilitary operations, with Malian and regional African workers manning the operations of UN agencies and NGOs up north. The reason usually given for this division of labor between frontline Africans and headquartered Westerners was the terrorist and kidnapping risk - the same risk that had already triggered withdrawals of staff in the preconflict years, when Al Qaeda in the Islamic Maghreb (AQIM) started extending its reach. By 2015, this security-based division had been replicated in other parts of the region, or as one NGO emergency coordinator told me, speaking of Boko Haram-threatened areas in northern Nigeria: "If your complexion is anything less than a Nigerian's, you won't really be going." Not only was the map of intervention here being divided into safe and unsafe zones, it was also being racialized in inverse relation to the jihadist strategy of targeting white-skinned Westerners.

Aid workers, like UN officials, lived under intricate rules regarding what transport to use and which areas were safe to visit even in Bamako. One embassy that I visited was relocating away from a route close to the presidential palace because of fears of becoming a target of irate demonstrators; yet as one resigned embassy employee told me, "You can't be $100 \%$ prepared all the time. You must get on with work and life as well." One NGO had plastered maps of no-go areas on its wall, including neighborhoods within Bamako as well as all areas outside the city limits. Meanwhile, European Union (EU) military trainers, whose hotel-based offices were set behind tall fences, were not allowed to venture into the north. Instead, they trained their Malian counterparts and waved them off toward the northern front lines, where brutal clashes were to occur during that May of 2014, as the following field account illustrates.

\section{Lockdown on the Niger}

The trouble started with a visit by the Malian prime minister to Kidal. The northern town had been left as the MNLA rebels' bastion after the French intervention, much to Bamako's chagrin. The French were playing a double game in the north, keeping the MNLA as allies while routing jihadists in the hinterland, and the premier now wanted to give this arrangement a push as he arrived in Kidal on May 17 with the intention of showing support for patriotic locals and state administrators.

He failed. As the prime minister tried to make it into central parts of Kidal, armed men took officials at the town's gover-

9. Figures from the Department of Peacekeeping Operations website, http://www.un.org/en/peacekeeping/resources/statistics/fatalities.shtml (accessed July 21, 2015). 
norate hostage. Then, as Malian forces attacked and French and UN soldiers stood by, the hostages were executed.

Soon, protests began. On our grainy guesthouse television, I saw protesters screaming into the night in downtown Bamako: rumors had it a UN vehicle had been torched. The next day, aid workers were scrambling to exit the north, but no flights were leaving. Anger against perceived UN and French inaction in Kidal was mounting, as was anger against northern Tuaregs and Arabs, seen as partial to the separatist cause. Mali was yet again a tinderbox about to ignite; yet the Kidal events were but the start to the cruellest week Mali had seen for some time.

"Have you heard the news?" I was in a plush hotel in northern Bamako on the night of May 21 when a European researcher broke the latest developments to me. Malian forces, some of them recently trained and equipped by the EU, had attacked the rebels in Kidal without informing the French or MINUSMA; then the MNLA had routed them. Kidal had fallen, followed by Menaka further south. "The Malian soldiers just ran away," the researcher said; they hid in the UN camp while the rebels stole their EU-provided vehicles. We walked upstairs to the hotel restaurant, set on a terrace brimming with soldiers and UN workers, to dine with a friend of ours from an NGO. What would the implications be down here in Bamako?

Over dinner, our friend looked out over the gathered men in uniforms. "I shouldn't really be here," she said, but let it be. Bamako's expat humanitarians tried to keep separate from the military, yet socially speaking, this was proving impossible; they mingled on the same circuit, stuck in the same high-end haunts. Our researcher colleague was nervous, too; she was not allowed to go anywhere by foot, according to new security instructions from somewhere. (Her embassy? Intelligence? She would not say.) Instead, she borrowed our friend's designated driver and left, as the NGO worker confided that she, too, was not really allowed to move around this area after dark.

After a nervous journey back that night, I awoke the next day to a Bamako in lockdown mode. Angry crowds gathered outside MINUSMA's headquarters and the French embassy's antiblast barriers. My meetings were cancelled. International organizations told their staff to stay indoors and away from the center. An interviewee from the EU training mission could not meet with me, he explained, because they were in "alternative planning" for the foreseeable future: military officers could not leave their barricaded hotel without security escort, and their barracks outside the capital were under curfew. Up north, further protests were brewing, and aid workers started evacuating the city; the situation was swiftly getting out of hand.

The protests and the rekindled northern troubles, which were eventually quelled as the Malian government softened its tone, revealed the fragile hold of international interveners on the north. Having failed to capitalize on initial local trust, the UN and France had instead built more distance from local society, paving the way for a spiral of negative rumors and resentment. Meanwhile, the Malian state was withdrawing its scattered presence up north, including its forces. The efforts toward breaking the northern deadlock had taken a big hit, and the divide between south and north - and between operational headquarters and northern hinterland-was growing deeper than ever.

\section{The Interventionist's Dilemma}

This brief account of Mali's troubles and the internationals' role in it may recall what Lianos and Douglas (2000:110-111), in a prescient piece, called "dangerization," or the growing Western "tendency to perceive and analyse the world through categories of menace." Their focus is criminological: as an example, they give a middle-class driver speeding past a housing estate because of the potential danger therein, and they ask whether a new "norm of distance rather than proximity" is being forged in Western societies. The speeding driver is, however, an apt metaphor, too, for the wider Western and UN engagement with global danger, as seen in the bunkers and four-wheel drives of Mali, as well as in the anxieties on show once such physical protections fail. Dangerization and distancemaking went hand in hand in Mali: risk aversion opened a gap between interveners and "intervened-upon" as well as between foreign and local workers. The result was not the quelling of danger but rather its proliferation, as seen outside the bunkered confines of the UN and the French embassy that May and in later protests during 2014-2016.

This trend toward distance is evident well beyond Mali, as already noted. In the UN sphere, Western withdrawal from dangerous peacekeeping missions may be said to have started in the 1990s, after the deadly UNOSOM mission to Somalia and the highly planned killings of Belgian troops in Rwanda on the eve of the genocide, yet it has accelerated in recent years. In non-UN military interventions, a similar pattern has evolved: instead of the mass deployments of yesteryear's Afghanistan, Western governments are now supporting proxies and dropping bombs, as in Syria or in Libya; deploying drones, as in Pakistan or Somalia; and training local soldiers to do the hard graft, as in Somalia or the Sahel-wide "Flintlock" exercise of the US military's Africa Command. Security is also being outsourced to a private military industry of multibillion-dollar revenues - a trend matched by the surging market for remotecontrolled weapons and surveillance systems. As for aid interventions, powerful Western funders have, in recent years, leaned heavily on NGOs and the UN to enter, stay, and "deliver" in distant danger zones, rather than exit them. Yet, as noted, these operations too are increasingly managed at arm's length, through local partners and staff. After Iraq, Western powers no longer want to put "boots on the ground," except for their most violent special operations, and they are not willing to risk "their" aid workers or journalists coming into harm's way. Western powers and international agencies increasingly face an "interventionist's dilemma" of ambivalent engagement and anxious withdrawal: stuck on the margins of danger zones, seeing them through the eyes of local helpers or the latest surveillance machinery. 
The relationship by remote control put in place here is on some levels a pragmatic response to both growing risks and cost-cutting demands, yet it is more than this, too. It involves the exercise of a detached kind of power, one aspect of which is the active transfer of risk down the social scale, toward regional peacekeepers or national aid workers, strengthening a trend in evidence from earlier post-Cold War conflicts and crises (Shaw 2005). Almost nine out of 10 aid worker fatalities now occur among national staff; meanwhile, in Somalia alone, some estimates list about 3,000 dead African Union peacekeepers in the African Union Mission in Somalia (AMISOM) operation, funded by the United States, the EU, and the UN to the tune of billions of dollars. ${ }^{10}$ A relationship by remote control also leads to growing "blank spaces" on our maps, from where little reliable information emanates. These blank spaces, as the next section will show, can easily be "colonized" by a complex constellation of dangers in an expansionary trend with troubling consequences for local society.

\section{Mapping Danger: Bundling and Placing the Threats}

Back in December 2010, I stood looking out over a smog-hazed Niger river from the offices of the EU delegation in Bamako, where I had come to interview a diplomat about irregular migration. By this time, things had not yet gone wholly downhill for Mali: Bamako roared with thousands of imported Chinese motorbikes, and its skyline was graced by Libyan-owned hotels. On street level, posters of Colonel Gaddafi next to the Malian president, Amadou Toumani Touré, showed who was bankrolling Mali's political class. What was missing, however, was the Western presence of earlier years, as travel advice had cut tourist numbers. On the surface, the reason for the changed advice seemed quite simple: worsening insecurity as jihadists had started kidnapping Westerners in Mali's north. However, there was a catch, as I heard during my interview at the EU offices.

The travel warnings were "pure politics," according to the diplomat. Rather than being based on actual threats, they were meant to force Mali to cooperate in crackdowns on terrorism, drugs, and irregular migration in the vast desert northEurope's top three priorities, with migration, in particular, being a key concern. "You hit people where it hurts, and that's tourism," the diplomat said, adding, "You could go and tap dance naked in Kidal, and nothing would happen."

Three years later, in November 2013, two French journalists were kidnapped and killed outside Kidal. By then, the political posters of downtown Bamako and the world they represented were gone: Gaddafi was dead following the NATO air campaign, and Touré was in exile after the spring 2013 coup, the country haltingly recovering from war. The north had become what European governments had preemptively announced in 2010: a no-go area of nebulous risks and dangers.

10. Ratio on humanitarians from Humanitarian Outcomes. The figures for the African Union are disputed; the African Union has given a much lower figure, at approximately 500 .
The idea of a danger zone may seem straightforward; if in doubt, just don't go. If you do go, you have only yourself to blame, as the UK and US governments have repeatedly shown, as they refuse to budge when kidnappers threaten to murder their hostages. Yet, in fact, the mapping of insecurity and danger - that is, naming and placing the threat-is itself a highly complex and controversial political act.

During those days in 2010 in Bamako, Malian tourist officials were fuming as a lifeline for the country's economy was being pulled away. Visiting the town of Djenne that winter, whose mud mosque was once a must-see on the Malian tourist trail, I would myself notice an anger that I had not felt on previous visits: children pulling faces and blank stares from adults, where before Mali's famous hospitality would have promised warm greetings and long discussions over pungent green tea. The withdrawal of tourism had not forced Malian cooperation, as the Europeans had wished; instead, it was simply ruining local livelihoods and stirring resentment against the meddling foreigners.

African politicians have often raised red flags over blanket travel advice, arguing that curtailing tourism may in fact fuel terrorism as local employment chances recede. ${ }^{11}$ There is no space to delve into this debate here; rather, by citing the EU diplomat, I simply wish to highlight how Western states have sometimes deployed the seemingly apolitical tool of travel advice in a bid to force cooperation on key political objectives. Moreover, his assertions reveal the "danger" of the danger zone to be a slippery signifier indeed. Instead of being simply about security risks toward (Western) citizens from terrorism, the diplomatic strategy for Mali bundled such risk with quite distinct "risks" (drugs, migration), all the while placing this bundle in a discrete geographical space. There is, in addition, a peculiar temporal time frame to this, as future probabilities of danger are projected into a rather generic spatial distance, as the following citation from a UK House of Commons report on North Africa and the Sahel also illustrates (my italics):

[In] Mali, an al Qaeda-ruled rump state was a reality for some months, and some of our witnesses considered that Mali's neighbors were potentially vulnerable to a similar fate. Niger and Mauritania were singled out, and Mali itself was not yet seen as being out of the danger zone. It is reasonable to assume that an Islamist statelet somewhere in north-west Africa would be a centre of smuggling, people trafficking and kidnapping; activities that already go on in the region. ... A rump state would have the potential to disrupt or destabilize its neighbors and-although this point is speculativelaunch attacks on more distant enemies. (FAC 2014:38)

A center for smuggling and people trafficking; the French defense minister echoed these concerns in May 2014 as his Mali-based forces were regrouping into the regional counter-

11. See, for example, the New York Times on coastal Kenya (Gettleman 2015) or the Guardian on Tunisia (Grierson and Mason 2015). 
terror operation Barkhane. "There will be 1,000 soldiers that remain in Mali, and 3,000 in the Sahel-Sahara zone, the danger zone, the zone of all types of smuggling," he told reporters. "We will stay as long as necessary. There is no fixed date" (BBC 2014). As he indicated, cross-border flows - drug trafficking and especially irregular migration - are here, besides terrorism, coming to function as key drivers of intervention; moreover, they are part and parcel of the constitution of certain areas as danger zones, taken (in both the UK and French examples) as no-man's lands rife with criminal activity.

Northern Mali-like much of the rest of the Sahel-Sahara belt-has, in this sense, come to play host to a potent "threat cluster" in the eyes of Western interveners. There is certainly a long colonial and postcolonial history to this construction. The Sahara, McDougall and Scheele (2012) have shown, has long been seen as a space of dangerous remoteness in the Western imagination, portrayed as "a deserted place, were the permanent struggle of humanity against nature has deprived people of one of their most human characteristics, namely, the ability to change and to creatively influence the course of events" (2012:9). Against this putatively empty, romanticized, and dangerous space conjured by the colonizing West, McDougall and Scheele assert the intricate connections linking different parts of the region. Focusing on these connections makes the Sahara come alive socially, or as they emphasize: "The only way we can fill the emptiness of the Sahara while avoiding long-standing stereotypes and misleading categorizations is by conducting research locally" (2012:16). Much the same can be said for other forms of engagement, from aid work to diplomacy and peacekeeping.

Yet here is the rub. Instead of gaining a local perspective, peacekeepers, aid workers, journalists, researchers, and UN officials have increasingly come to draw distance to the danger zone as the default option, thus reinforcing the region's remote and risky character. The desert danger zone of official imaginations here appears as a peculiar kind of "nonplace" (Augé 1995) ripe for certain kinds of interventionthat is, interventions focused on the overlapping threats to the West.

Besides the historical context of the Sahara, a more recent global frame is just as important in understanding the mapping of danger onto northern Mali. In the post-Cold War era, policymakers grappled with how to define the West's new geopolitical "others," and the most abject of these came to be known as the "failed state." Since the 1990s, the failed state has kept rearing its head in "gray" policy and academic literature, despite a substantial critique of its application as "mainly reflecting Western powers' policy concerns" (Nay 2013: 328) and of its diagnosis as flawed. When, in the midst of the French deployment to northern Mali in early 2013, the UK prime minister referred to the area as an "ungoverned space," he resurrected the failed-state paradigm in new garb, ignoring how too much state meddling, especially in northern Mali's drug trade, was at the core of the problem (Guichaoua 2013).

It is worth backtracking a little to see these superficial models of "political otherness" in their earliest, crudest forms. In an (in) famous piece, "The Coming Anarchy," Robert Kaplan (1994) set the tone for post-Cold War anxieties over the poor nonWestern world. His words sound rather prescient two decades hence, even though the anxieties he spells out have since modulated away from urban crime toward jihadism:

West Africa is becoming the symbol of worldwide demographic, environmental, and societal stress, in which criminal anarchy emerges as the real "strategic" danger. Disease, overpopulation, unprovoked crime, scarcity of resources, refugee migrations, the increasing erosion of nation-states and international borders, and the empowerment of private armies, security firms, and international drug cartels are now most tellingly demonstrated through a West African prism. . . To remap the political earth the way it will be a few decades hence - as I intend to do in this article - I find I must begin with West Africa. (Kaplan 1994)

Another important step in this radical "remapping of the political earth" was taken a decade later by an influential American geostrategist. Setting out a road map for US military interventions, Thomas Barnett (2004) divided the world into its developed "functioning core" and the "non-integrated (or non-integrating) gap." The latter referred to regions beset by instability that may breed future terrorists (Masco 2014:187), and Barnett emphasized the need to focus military interventions in this gap. As areas "where people still go medieval on one another" (Barnett cited in Keen 2012:188), here any means were allowed, he argued, including preemptive war. Barnett's (2004) theories have given intellectual gloss to new counterterror tactics, mapping "the everywhere war" against terrorism (Gregory 2011) onto discrete and distant sites. Besides Barnett's gap, another example of such mapping is what analysts and diplomats refer to as the global "arc of instability," which in one of its various versions extends from the SahelSahara region to the Horn of Africa and onward, to the Afghanistan-Pakistan borderlands.

Official worry about the arc of instability and its multifarious dangers was central to international interventions in Mali, as I noticed in interviews in Western ministries during 2014 and 2015. One high-level French diplomat, for instance, reframed and renamed the wider geographical region in terms of danger. To him, "when we speak about Sahel it goes from Nouakchott [Mauritania's capital] to Mogadishu. For me Somalia is Sahel; it is one world." His reason for this redesignation was that the armed groups active there, from al-Shabaab in Somalia to Boko Haram in Nigeria and AQIM in Mali, shared the same ideology and so shared the same "culture." A highly placed European military officer offered a similar regional remapping. "We have to see Mali in the larger picture.... MINUSMA is part of an entirety that starts in the Gulf of Guinea and ends in Somalia," he said. However, he added a different emphasis as he drew a mental map, plotting one existing military or humanitarian intervention after another along this arc. He continued: "Which risk is it really that we are trying to handle in Mali?" The unspoken answer was princi- 
pally (though not exclusively) migration. Elsewhere, in one northern European foreign ministry, a map drawn on a whiteboard for an internal meeting showed how these multiple threats converged as they approached Europe: on it, arrows pointed outward from Libya's conflict, representing "IDPs" (internally displaced persons), "migration," and "terrorism." One UK diplomat, meanwhile, talked of his country's rising interest in the Sahel in terms of "turning off the tap" of migration, as well as about the risk of the arc of instability expanding. This arc has become so commonsensical that it now even has its own moniker: the "banana of badness," as the diplomat admitted with a giggle.

In sum, Western states are increasingly mapping out a discrete field of intervention defined by bundled and overlapping dangers, a "threat cluster" in which one kind of threat may nest within another, and so generating and reinforcing a generalized sense of danger and a concomitant will to intervene. In this way, systemic issues and risks - terrorism, migration, and criminal activity, driven as these are by global dynamics of supply and demand, of mass-mediated imagery and worldwide financial flows - are projected outward, away from the (Western) "core," in Barnett's term (2004). Although this process may seem to work in Western officials' favor, because it shifts the debate away from complex (domestic) policy areas toward a distant geographic space, a grounded perspective complicates this top-down view somewhat.

In interviews with front-line officers dealing with the danger zone, I came to see how they were ambivalently positioned between the political priorities on risk and the challenges of carrying out their daily tasks in a region beset by uncertainty and overlapping agendas. To take one example, Anders was the chief of one of the two European peacekeeping contingents eventually sent up to northern Mali, the Swedish one (the other was Dutch, based in Gao). As I met him before deployment to a new Timbuktu "supercamp" in January 2015 in the Swedish Armed Forces Headquarters, he was the rising star of the military: news stories had feted the Swedish deployment and Anders' role, even as the reporters' questions mainly concerned one topic - the risks to Swedish soldiers in the field.

Anders downplayed such risks, however. He and his troops were special forces whose skills had been honed in Afghanistan, like many other soldiers and contractors who were now arriving into Mali. "We are not half as worried as any enemies would be; in firefights, I think no one is capable of defeating us," he said. He had reason to be calm: like their Apache helicopter-equipped Dutch counterparts, the Swedes were extremely well equipped and well prepared, unlike the African peacekeepers. Moreover, their task was intelligencegathering, including via drones, rather than patrolling and securing areas, which was a much more dangerous task again largely left to the Africans. Intel is normally "cold, wet, boring, and monotonous," Anders quipped, "and now it will be hot, dry, and monotonous."

Anders' mission was mapping of a tactical sort: to trace and pinpoint elusive insurgents and foil their growing attacks on
UN peacekeepers in Timbuktu's tense hinterland. One key obstacle here was the narrow national remit of UN intervention. Anders drew a map with arrows (representing terrorist groups) branching out across the Sahel, similar to those I had seen in European foreign ministries. "We can squeeze the Coke bottle a bit here," he said, adding a squiggle, "but then the problem just bursts out somewhere else."

Unlike the ministries' conceptual maps, however, Anders' was more pragmatic and tactical. He knew time was of the essence and that "if we don't take risks, we end up facing a much larger risk." The UN camps sucked scarce water out of Mali's northern soils, and the soldiers' heavy trucks ground down fragile roads; local patience would not last forever, as I had seen during the protests in Bamako. Aware of local discontent, Anders deplored the lack of aid interventions, seeing these as a crucial part of rebuilding the north. As for his men, he was, after many years on external missions, mindful of political risk aversion once casualties were taken. Instead of withdrawing at the first sign of danger, he hoped that "everyone will be patient and recognize that this will take time."

Such concerns, similarly expressed by peacekeepers and aid officials I met in Bamako, showed some of the limits of the Western "cartopolitics" of danger. Despite the official talk of a "single reality" of the Sahel/Horn of Africa belt-a "banana" ripe with "badness" - practicalities and politics constantly got in the way. The UN machinery was creaking, and local resistance was too fluid, while the French, British, and Americans were still, to some extent, ensconced in their geographical silos. Grand visions for the Sahara, much as in the early French colonial times, were blurring amid the shifting sands of Mali's rebel politics and the limited resources at the interveners' disposal. As Monica, the UN administrator, was eventually sent up north, she told me by Skype how she was being tasked with almost single handedly managing a military camp attacked by rebel missiles, hamstrung by a lack of provisions, and protected only by risk-averse and ill-equipped African peacekeepers. "Remote control," Monica and others on the front line knew, did not offer much control at all.

To conclude, crisis-hit and chronically neglected areas, such as northern Mali and the wider Sahel-Sahara belt, are coming to constitute, from the point of view of interveners, a peculiar object of intervention. They are principally of concern as host to a set of bundled dangers - a threat cluster - yet that cluster becomes increasingly hard to address thanks to our very aversion to assuming risk. As has been seen, this interventionist's dilemma is increasingly resolved by recourse to remote controls, whether via technologies such as drones or via reliance on regional forces, national aid workers, and other groups willing or forced to shoulder risk. Yet such measures often dramatically implode or simply fail to deliver, leading to novel dangers and further withdrawal, and so to more reliance on local or regional eyes, ears, and hands. Such reliance in turn opens up new avenues for local engagement with the apparatuses of intervention, as will be seen in the next section. 


\section{Mobilizing Danger: Reflexive (In)securitization in the Danger Zone}

The Sahel is host to chronic and underfunded crises, including food insecurity, recurrent droughts, climate change, high population growth, and gloomy economic prospects. Yet these issues are increasingly addressed by Western donors, if at all, as root causes of immediate threats. In the UK Foreign Affairs Committee report on the Sahel, for instance, the Foreign and Commonwealth Office warned that Islamic extremism in the region "is an increasing threat to UK interests" and "that a failure to increase engagement would carry greater risks." Increased engagement here means not just traditional security, as UK Defense Secretary Michael Fallon has made clear when discussing defense versus development spending: "The biggest problem we are facing now, in Libya, in Liberia, even in Nigeria where they have lost control of the northern province, in Sudan, in Yemen ... is that these states are starting to fail and that's where in the end-sadly-you end up having to intervene with armed force. So these aren't opposites. [UK Development Secretary] Justine Greening's budget and mine you should add together; they are security budgets" (Forsyth 2014).

Such assertions are not new; in fact, they significantly predate 9/11, as Gupta (2015) has shown in a recent review on the construal of poverty as a security threat. Duffield (2001:4-5), in his seminal work on the securitization of development, has put this trend in relation to changes in global capitalism, much as Goldstein (2010) does in relating security discourse to neoliberalism. As capitalism has shifted from a logic of (unequal) inclusion to a logic of exclusion since the 1970s, Duffield argues, development programs have been reshaped and "securitized." Global exclusion, he insists, thus does not involve the complete closing of doors; rather, the "strategic complexes" of global liberal governance (involving intergovernmental organizations, donor governments, and other powerful actors) have fomented a "subordinating social relationship" with target populations and nations, shaped around the notion of underdevelopment as a threat (Duffield 2001:5).

Although the securitization debate has generated prolific writings (for one recent intervention, see Pugh, Gabay, and Williams 2013), the process is rarely discussed from "the other side" - that is, from the perspective of aid recipients and intervened-upon populations in the danger zone. A key question arises in this interaction, namely: What happens when your main asset becomes the risk that you constitute to others?

In Mali's north, jihadist groups have certainly exploited the risk aversion of Western states through spectacularly violent acts against kidnapped victims, disseminated as "propaganda of the deed" over social media (Bolt 2012), much as in other settings, such as Libya or Syria. In this sense, violence and insecurity are highly interactive, as our imagining of catastrophic threats is increasingly realized in real time through murders perpetrated for political gain. However, this section is principally concerned with the more subtle effects of West- ern donors' catastrophic imagination of the danger zone and its noninsurgent inhabitants.

During fieldwork in Mali in 2010 and 2011 on migration, I would see how actors positioned themselves in direct response to European priorities. The police, for instance, used the "risk" of irregular migration through the Sahara as a way of pushing for more development money. "Europe needs to help us with projects in villages. That way, people can become sedentary," pleaded one border police chief as he complained that EU money was only for "fighting illegal migration." Then he proceeded to ask for funds on both fronts. "If you want to fight effectively against illegal migration in the north [of Mali], you have to create a system in the style of Frontex [the EU border agency]," he said, invoking European border patrolling operations at sea. "But we too," he exclaimed, "we have an internal sea; our sea is the Sahara!"

The Malian gendarmerie expressed similar sentiments as they called for more resources to patrol Mali's long borders: new border posts, computers, generators, vehicles, and even petrol for these vehicles. These demands were justified, again, by recourse to the threat cluster delineated above. To the gendarmes, Central and West African migrants-suspected of migrating irregularly to Europe, deported by Algeria into the desert, and then left stranded in Mali-incarnated Europe's concerns. "We need to have a transit center [for deportees] in Kidal or Gao and another in Bamako. It's what we told [the European partners]," one high-ranking gendarme told me. "If not, once they arrive here they have nothing. They'll steal, rob, even kill, or they can be recruited by AQIM. It's a big problem."

As the Malian forces' "securitization" of migration indicates, the best way to have the ear of Western donors was to invoke the terrorist threat. This was the case not just for local forces but also for civil society groups, as one humanitarian association in Gao exemplified to me in 2011. The association, set up to care for migrants deported from Algeria, aimed to reinsert deportees socioeconomically and to create local development projects to "keep the youth" from leaving. The youngsters of Gao, one of the association's leaders explained, "have nothing to do and so they risk heading off on migration, or they risk becoming drug traffickers, get involved in prostitution and all that, or what is even more serious, they risk becoming coopted by local militias or assimilated into organizations such as al Qaeda. They [AQIM] are ready to come into town nowadays, to take these youngsters and insert them into their structures. This is our big fear."

On official levels, the same pleas were in evidence. In April 2014, to give one example, the Malian president signed an agricultural accord with Morocco at a UN-sponsored conference by which Moroccan investors could exploit a large tract of fertile land around the Niger river. "The development of agriculture in sub-Saharan Africa will certainly prevent these young Africans from emigrating or joining terrorist cells operating in the wide and vast desert of northern Mali," the president said, motivating the controversial decision (Benmehdi 2014). 
These statements are but some examples of how a reflexive (in)securitization of the self is taking hold in the danger zone, as I would also see to some extent with friends active in Senegal and Mali's associative sectors.

As I had returned to Bamako in 2014, one of my first ports of call was the southern neighborhood of Magnambougou and the home of a friend and earlier research participant, Djibril. As I called on him, I knew times were tough. Djibril was a deportee from Spain and had been involved in one of the associations of "returnees" set up after his and other migrants' expulsion from Europe and Morocco. Through this association, Djibril had managed to ensure on-off work on projects funded by international organizations. Yet as the 2012 conflict began, donors and Western NGOs took flight, leaving Malians such as Djibril without employment. As I called on him, I knew I was expected to bring solace of some kind: my proposition was that he could work as my research assistant.

Djibril's frustration was palpable as we spoke, sitting in his communal courtyard around a brewing teapot as his children came and went. "You see, there are no jobs, what can we do? We have to leave, don't we?" I nodded yes, but I told him not to forget the dangers on the road. He equivocated; perhaps he did not actually want to leave again. The sun set over the yard as Djibril kept talking; a strip light flickered to life atop his door and his children gathered on the bench underneath, schoolbooks in hand. "So this is why the youth go and join Mujao (Movement for Oneness and Jihad in West Africa, one of Mali's jihadist groups), or go take a boat to Spain, or die in the desert," Djibril said, continuing along the lines of his earlier argument as I shifted awkwardly in my seat.

As a marginal participant in the aid nexus of Bamako, Djibril had bought into the mobilization of danger so present in the relationship between Malian authorities, NGOs, and their international partners. He was, in a not-so-subtle way, using the risk of his own potential to migrate to make sure that I kept to my word and employed him. However, he was also critical of this remaining pathway to engagement. Another day, we had lunch together after meeting an IDP leader who had frustratingly talked to us about the lack of support for the displaced in Mali while false beneficiaries "ate all the money." Pondering this pilfering, Djibril said, with a flat laugh, "In order to be rich, you have to threaten. In our [deportee] association, we have 1,000 members; we buy some arms, make a [black Islamist] flag, take a Westerner hostage, and we've solved it!"

I might have let this statement pass as simply a one-off show of sarcasm if it was not for its resonances with what officials such as those above were saying, or indeed with similar arguments from other underemployed aid brokers. In my research on irregular migration in 2010, I had been told by members of Senegalese deportees' associations similar to Djibril's that they were the ones who were really "fighting migration," unlike the police or the NGOs that were running risk-awareness campaigns with European development funding. One day, for in- stance, I was walking along the beach with the leader of one association, Mohammadou, as he pointed toward a vessel at sea. "Look at the boat out there! It's the garde espagnole." The Spanish Guardia Civil's patrolling vessel came every day, he said; its principal task was to deter any departures toward the Spanish Canary Islands, which Mohammadou had once tried to reach. "It can't stop us," he insisted. "If no money comes soon from Europe, we will set off again. ... This time we'll be 100,000 , or thousands of 12 year olds." It sounded like a warning from someone aware of both the depiction of migrants as a threatening force and the legal constraints in deporting unaccompanied children. The deportees' effort to convince impatient youth to bide their time was the reason no one was leaving, Mohammadou made clear. "We are waiting now for any development projects to come through from Europe," he insisted. Their patience would not last forever.

These brief vignettes are simply meant to indicate some of the more overt ways in which danger or specific types of risk may be mobilized reflexively by those seen as being both risky and "at risk": the youth of West Africa who Kaplan (1994) once described as "loose molecules in a very unstable social fluid, a fluid that was clearly on the verge of igniting." Approached systematically, such self-fashionings may open a window onto the new relationship forged between the inhabitants of designated danger zones and the international community. Besides showing an acute awareness of Western priorities, they also serve as commentary on the local effects of the mobilization of danger and the reorganization of intervention. Djibril, along with many other Malians I spoke to, insisted on the erosion of the country's much-celebrated culture of trust, generosity, and welcoming (djatigiya) since the time of the conflict. Yet in bemoaning this apparent erosion, locals such as Djibril were simultaneously reasserting their shared values of dignity, joking relationships, and national identity at the heart of postindependence Malian society (see Whitehouse 2013). In the equivocations and ambivalences, an opening may be found for alternative pathways for engagement, mobilizing local opportunities, rather than catastrophic imaginations of clustered threats. Here anthropologists will have plenty to contribute to larger debates on international intervention as we grapple with the reflexive nature of global danger and its local contestations and mobilizations, and so "returning the gaze" (Charbonneau 2015:7) onto powerful systems of intervention that have all too rarely faced such ground-level scrutiny.

\section{Conclusion: Anthropology among the Dragons}

This article has delineated some salient aspects in the emergence of "danger zones" of the kind seen in Mali, with clear parallels elsewhere, from the Somalia conflict to Libya's postGaddafi chaos or the remote "war on terror" in the AfPak borderlands. In all these settings, new models of intervention premised on distance and bundled dangers are emerging. However, as has been seen, these models are not easy to impose. From the perspective of powerful states and actors, it 
should be clear how difficult it is to withdraw in an otherwise wired world, and how large efforts have been expended on various levels to achieve this objective. Distance is physical: international interveners withdraw key humanitarian, political, and even military staff from the front line; build bunkers in the "field"; and develop new technologies of "remote control" via drones, satellites, and surveillance. Distance is social: interveners outsource risky tasks to local staff, mercenaries, or freelancers, deepening the divide between "local" and "expat," former colonizer and colonized. Distance is conceptual: donor governments and international organizations promote new buzzwords and theories that end up acting as metaphorical containers for "others" affected by insecurity. And finally, distance is psychological: as "we" in the West withdraw from danger zones, we are paradoxically tied more closely than ever to these new no-go areas. Insurgents, knowing this, may then tap into our fear with the help of a simple pocketknife and a webcam. For as the Control Risk executive said at the launch of the Risk Map mentioned above: "There is no longer any such thing as far away."

There is much else to be said about the mapping and making of danger zones; of how, all else failing, Western states concentrate on simply containing "threats" emanating from these zones through ever-tougher border controls; of the psychological pull of danger on certain chance-takers, from daredevil freelance reporters to volunteering fighters; or of the brutal connectivities generated by supposed distancing devices, as seen in the "voyeuristic intimacy" of drones (Power 2013). However, I will end this piece with a brief overview of the larger global picture of risk, hinted at by that Risk Map citation in the preamble.

"As the bipolar world fades away," Beck (1999:3) wrote in his World Risk Society, "we are moving from a world of enemies to one of dangers and risk." This may now seem rather prophetical; yet as danger and risk are gaining salience, we need to recall that risk should not be seen exclusively through a negative prism. Risk is rather double-edged, source of both fear and gains, as seen, for instance, in speculative global finance. Ever since the 1970s oil crisis and the financial revolutions that followed it, the global economy has thrived on risk, engendering a fundamental contradiction between increasingly risk-averse citizens and politicians and the premium put on rampant risk-taking not just in banking (financial risk) but also in sectors such as private security and mercenary activity (security risk).

Risk is not just unevenly appreciated by different social groups and sectors; as this article has shown, it is also distributed unevenly across our world map. In her work on the global geography of capitalism, Sassen (1991) has shown the financial world to be condensed into "global cities" functioning as one-stop shops for speculative capital. Standing in sharp contrast to these are similarly "extreme zones" for "new or sharply expanded modes of profit extraction" (Sassen 2014: 18): manufacturing hubs such as China's Shenzhen or the land-grab terrains of swathes of sub-Saharan Africa. These spe- cialized sites in the world economy, Sassen (2014) shows, depend on a transfer of risk from costly Western laborers to poorer counterparts, from bluechip companies to subcontractors, and from mining groups to the villages or habitats they destroy. With this global map of risk distribution in mind, the remote danger zones of concern here may be seen as similarly specialized, but not in producing goods or forging out credit default swaps. Rather, they serve as sites for the manufacturing of one important "product" in contemporary world markets: insecurity or danger. They also serve as zones in which the risk transfers prevalent elsewhere in our economies are taken to their most extreme, as the powerful withdraw from view and leave more vulnerable groups to deal with the dangers.

"Dangerization," in short, has gone global in uncontrollable ways. As anthropologists, we may investigate this process along many overlapping vectors, as this article has shown. We may explore how risks are apportioned and transferred socially, geographically, and through new technology; how dangers are conjured, clustered, and spatially mapped out; or how locals subvert or reinforce these impositions. We may also take a broader view, critically returning to our disciplinary beginnings in the marginal territories of the early colonial world, as well as to the precolonial fears and desires that steered early explorers' quest for the unknown.

If we do so, we may see that, unlike in early colonial times, the rewards that entry into the danger zone hold up are no longer (or not only) the putative riches that once led explorers such as the Frenchman René Caillié (1992) toward Timbuktu. Even though oil, gas, and minerals do retain their lure, today's gains are principally negative in kind; they are not about conquest but about control. For here, in the heart of the danger zone, lies the promise of converting uncontrollable danger into manageable (countable, containable, and "killable") risk. Much like Caillié's frustrated quest to discover Timbuktu's long-lost riches, this dream of global power is, however, a losing prospect, as this article has shown, and a rich one to explore for an anthropology critically attuned to its past and open to its tense global present. Those Medieval monsters with which I began have yet again come to infiltrate the edges of our Google-era maps; worse, a growing Western fear of venturing into their domains is now steering intervention and involvement, creating a spiral of negative dynamics from which it becomes increasingly difficult to extricate ourselves. Here anthropologists, thanks to our legacy of studying the remote and the marginal, may play a trickster role in weaving back and forth between the inhabitants of the danger zone and international interveners, and between executive headquarters and the new blank spots on the map, straddling the danger zone and its manifold contradictions.

\section{Acknowledgments}

I am very grateful to Ana Gutiérrez Garza for very helpful feedback; to Florian Weigand for sharing findings from Afghanistan; to Mary Kaldor and my former colleagues at the London 
School of Economics and Political Science for encouragement and inspiration; and to Martin Saxer for very fruitful discussions and ideas on remoteness and connectivity. I am indebted to the anonymous peer reviewers of this article, who provided invaluable comments, and to the Current Anthropology team for seeing it into print. Finally, I am grateful to the AXA Research Fund for my Postdoctoral Research Fellowship, 2014-2016, which has enabled me to carry out the research for this article. The views expressed are mine and not those of the funder.

\section{Comments}

\section{Nicholas Farrelly}

Coral Bell School of Asia Pacific Affairs, Australian National University, Canberra, ACT 2601, Australia (nicholas.farrelly@anu .edu.au). 14 IV 16

\section{Dangerization Is Risky Business}

Those of us who study Asia's highlands have benefited immensely from the notion of "Zomia" as first imagined by Willem van Schendel (2002) and later popularized by James C. Scott (2009). Zomia, as an idea, helps to explain how lowland civilizations have struggled with rebellious highland peoples, many of whom have fought, on an almost permanent basis, against assimilation, integration, and worse. As a model of center-periphery relations, it has the advantage of reprioritizing the experiences of those too often dismissed as marginal to both power and knowledge. Van Schendel's original Zomian argument is about redrawing the maps in our minds: it is as much an argument about the power of academic delineation as it is about the power of lowland armies. In this article, Ruben Andersson does not pull van Schendel or Scott into the conversation. Instead, what he offers is an ethnographic map of "global danger": a Zomia writ large. Andersson helpfully challenges us to consider "dangerization" to better understand how risk intolerance impacts our ability to influence the world. Framed as an anthropological response to the proliferation of "no-go zones," he gives a shrewd impression of such danger, while keeping himself, and his own attention, mostly on the "safe" side of the divide. Andersson offers a reflection on the lands of dragons, mostly through a mirror of sturdily constructed conceptualization.

In Andersson's explanation of the "interventionist's dilemma," perhaps the most strikingly constant message is about "Western" interests. This curiously old-fashioned binary makes sense in Mali and across the Sahel: I would suggest it is redundant in many other places. Indeed, the emergence of new forms of colonially minded resource exploitation, as we see in the many places where muscled-up Chinese businesses make investments, means that global risk is an increasingly global preoccupation. With so much attention on those he calls "Western citizens,"
Andersson stamps his European concerns on the map of global danger. It turns out to be fascinating. What Andersson offers is a sharp interrogation of the boundaries and categories established to guide interaction with "danger zones." We learn that, because of institutional and personal constraints, Andersson remains distant from his dangerous field, just like the "Western interveners" he critiques. While the overall argument is intriguing, I wonder whether the circularity that it implies misses the most fundamental challenges of a world where getting killed, kidnapped, arrested, mangled, or mauled is not, for many people, a theoretical suggestion. Some might conclude that, with Andersson's critique, the dangers sketched out by risk consultants, government officials, military personnel, insurers, and others are mere abstractions. Often, they are not.

One of the reasons that risk management is such a vast and lucrative industry is that it should require specialist input to help explain grounded experiences in an ever-changing world. During the 15 years that I have been undertaking field research in and around Myanmar, I have seen the levels of risk, as quantified by analysts, and danger, as felt on the ground, rise and fall. From week to week, month to month, and year to year, profound changes in conditions have influenced research opportunities and constraints (see Farrelly 2012). This "oscillation," a Leachian (1954) flourish, explains the need for continuous assessment, close engagement, deep immersion, and logistical adjustment, as well as for patience. There is simply no steady state for "global danger" or its multitudinous local interpretations. Andersson reminds us that these circumstances reward those prepared to commercialize risk by bundling it for those who need to have it managed.

Furthermore, Andersson explains that "Western" intervention can deploy techniques of "remote control," literal and figurative, to support claims in places that remain dangerous. I wonder whether this situation is as novel as it initially seems. The reason that unruly spaces are allowed to persist is that their comprehensive control is not essential. This is an argument about "nodes of control" that I have made elsewhere (Farrelly, 2013), drawing on research in the disputed and often violent India-Myanmar borderlands. Where governments can maintain "nodes of control," there is little incentive for deeper engagement. Technologies that allow for power projection and surveillance are ideal in this respect. The strategic value of such nodes is not just found in Zomia, or in Africa's "arc of instability." It is also not a coincidence that the phrase "arc of instability" once gained much attention among those who consider Australia's strategic landscape (see Ayson 2007; Wallis, 2012). If we take seriously the idea that danger blurs into our own lives, then we need to think more about the extent to which nodes of control may shape a great diversity of spaces around us.

In his conclusion, Andersson argues that "a growing Western fear of venturing into [dangerous] domains is now steering intervention and involvement." Under these conditions, social scientists of all stripes have some responsibility for understanding and interrogating grounded conditions, especially 
in those blanks spots on the global map. But with such modes of assertive engagement, there are practical concerns. Field research in conflict zones and adjacent areas requires a portfolio of skills that most of us struggle to maintain. Situational awareness, a military term, is the foundation for survival. Anthropologists and their fellow travelers should be well-equipped to engage with our dangerous world. The problem is that too often our own assessments are outsourced to distant bureaucracies and those who struggle to put the risks in their rightful contexts. Even when done well, risk assessment - a flawed, human undertaking - is still imprecise and artistic. For this reason, Andersson should be commended for his superb appraisal of this persistently relevant topic. Whether we are talking about Zomia or the Sahel, our analysis will matter both for those whose will face some of these dangers and for those who prefer to stay at home.

\section{Gabriella Körling}

Department of Social Anthropology, Stockholm University, Stockholm 106 91, Sweden (gabriella.korling@socant.su.se). 29 III 16

At a time of increasing anxiety over terrorism and migration and of concomitant security measures, Andersson's article offers a welcome critical perspective on global concerns with security. Andersson convincingly argues for the need to focus on how "global forms of insecurity and danger are conjured, mapped, and intervened upon." Theoretically, Andersson engages with critical security anthropology. Ethnographically, his account is anchored in Mali and the surrounding region. Drawing on his own fieldwork on international interventions in Mali, a country in which large areas nowadays are classified as "no-go zones," Andersson addresses the methodological, ethical, political, and analytical challenges for anthropology at a time when "'security' is now everywhere." Recent years have indeed seen the increasing dominance of a security agenda not only in conflict-ridden Mali but also in neighboring countries, who now find themselves at the forefront in the fight against terrorism as part of an "arc of instability" and "terrorist hot spots" that stretches from the Sahel to the Horn of Africa. International interest and intervention in the wider Sahel region is thus increasingly filtered through a concern with security and the "global" threats posed by terrorism. Andersson argues that this has wide-ranging consequences for local societies that become increasingly marginalized and disconnected, as previous contact points, such as tourist flows, are cut off due to security concerns at the same time that they are "unevenly incorporated into the world economy of risk." While Andersson does a good job in uncovering the processes that go into the conjuring up of danger and insecurity, it would have been interesting to read more about the different components of this world economy of risk and insecurity in general, but especially so in the case of Mali. The description of security agencies and experts gives one indication, but what are the manifestations of this world economy in Mali in particular?

Andersson's "ethnography of danger" starts with a reflexive account of his own dilemma as he was preparing for fieldwork in Mali and was faced with travel advice and security staff that told him not to go to northern Mali, colored in red on maps of the country to indicate its status as a "nogo" zone. Andersson thus raises the question of how to deal with such warnings. Does one chose to enter or to stay away? What are not only the methodological but also the political and ethical consequences of such decisions? What are the implications for anthropological engagement when favorite field sites become new "danger zones"? Doing fieldwork in Mali and in neighboring Niger, I have been faced with similar dilemmas, especially in the last couple of years. During an ongoing research project in Mali, at one point at the high point of tensions between the 2012 coup d'état and the French military operation, my colleague and I decided not to go back to Mali. In an article, we reflected on our choice of alternative research strategies, as the "field" had suddenly become inaccessible (Hagberg and Körling 2014). Andersson goes a step further, as his account of his methodological dilemma also points to the importance of reflecting on our own fears and vulnerabilities at the same time that we critically examine the political processes behind the increasing dominance of concerns with insecurity and potential danger.

In the end, Andersson decided not to cross the "red line" and to stay in Bamako, revealing a certain discomfort by suggesting that this might have been a "cop-out." At the same time, he argues that it provided a reflexive starting point for exploring the consequences of the fact that more and more international actors choose to stay away from areas that are considered dangerous, thereby contributing to their increasing marginalization. The question that seems to remain or linger is what happens to the relevance of anthropology if withdrawing means that we can no longer contribute with perspectives and the experience of local inhabitants living in areas labeled as dangerous and insecure.

Andersson's ethnography of the emerging security landscape in Bamako brings us into military and diplomatic offices and headquarters. These are places that are still relatively understudied, perhaps because of their seeming inaccessibility, despite an increasing interest in and awareness of the importance of "studying up," which in this "aid dependent" region is often rendered into ethnographies of international development actors and policy or state bureaucracies. Andersson makes an important point about the changing "geography of intervention" whereby both military and humanitarian interventions are to a large extent piloted from Bamako. This situation is maybe most strikingly symbolized by the implantation of MINUSMA's headquarters in one of Bamako's luxury hotels. Andersson's analysis reveals a hierarchy of risk as African contingents of peacekeepers and local NGO staff are sent to the still-unstable north at the same time as the mobility of 
Western expatriates is circumscribed, even in Bamako, due to security concerns.

Andersson also points to the conflation of perceived threats, such as terrorism, migration, and crime, that are then mapped by Western diplomats and security experts onto the same geographical space, determining future interventions. This conflation is also evident in Niger, where the EU Common Security and Defence Policy Mission in Niger (EUCAP Sahel Niger), a part of the EU regional strategy for security and development with the mission of combating terrorism and organized crime since 2015, is also supposed to contribute to "stemming irregular migration." The increasing dominance of the so-called security-development nexus and its consequences certainly needs to be critically examined by anthropologists. At the same time, the concern with security has also opened up new funding flows, as the language of security is appropriated by local associations and NGOs in their attempts to access the "development rent" (rente du development; Bierschenk, Chauveau, and Olivier de Sardan 2000). Here security is merely, and less dramatically, simply the latest priority imposed by international funding agencies.

In charting the possible contours of a "global ethnography of danger," Andersson clearly illustrates not only the potentialities but also the urgency of an anthropological analysis of the security agenda in the Sahel and beyond.

\section{Mark Maguire}

Department of Anthropology, Maynooth University, Maynooth, County Kildare, Ireland (mark.h.maguire@nuim.ie). 16 III 16

\section{(In)security in the Round}

Reading Ruben Andersson's fascinating article immediately called to mind a passage from Graham Greene's The Quiet American (1955). On the road from Tây Ninh to Saigon, the main protagonist's car runs out of fuel, and the passengers are forced to seek shelter in an unmanned watchtower. As night descends, it becomes clear that French Indochina is only French during daylight hours. Darkness belongs to the enemy, and so also does the future. As a foreign correspondent in 1950s Saigon, Greene experienced life in a danger zone, and his writing explores fantasies of control, from the geopolitical to the everyday and intimate. For me, Ruben Andersson's ethnographic study of distance in today's danger zones calls to mind other literatures and maps that provoke one to think about the spatial dimensions of security and insecurity.

This article calls for important methodological and theoretical discussions. I hope that it will raise awareness of the institutional pressures felt by anthropologists planning fieldwork in a moment in which even the word "overseas" conjures danger for university administrators and funding bodies. Surely graduate training programs also need to discuss safety more openly, although I question the wisdom of disseminating the specifics of security protocols. Andersson's theoretical deployment of Lianos and Douglas's "dangerization" is also venturesome. Ironically, however, the concept is itself a bit risky, potentially leading to what Fredric Jameson terms premature clarification, especially if coupled with all-explaining concepts like neoliberalism or risk societies. But others will give more fulsome methodological and theoretical comments. Here I simply underline the essay's spatial dimensions and suggest a few ways to extend the analysis by attending to verticality, temporality, and multiple vectors.

"Here Be Dragons" may be read as an exciting anthropological essay on space. It describes actual experiences in a danger zone, discusses real or imagined threats emanating from so-called blank spaces and the arc of instability, and points to the roles played by technological solutions that offer intervention at a distance. Ruben Andersson connects these different scales and spaces masterfully. But what if we were to place his discussion in a broader history of conflict, security, and everyday danger? I was reminded of The Quiet American because it opens a way into the vast literature on war and space that includes many germane discussions. Writing in 1938, for example, Bertrand Russell foresaw the dangerous alliance between aerial power, private forces, and the new morality inherent in (scientific) governing at a distance (Russell 1938). He foresaw, in short, the multidimensional exercise of power in terms of verticality. Today, important work is ongoing among geographers such as Stuart Elden, Derek Gregory, and others on the spatial dimensions of twentieth-century warfare, especially asymmetrical and counterinsurgency battle spaces. Thinking in terms of verticality extends beyond "the higher ground," historically speaking, because it allows us to explore how violence and terror are deployed in such a way as to draw distant battle spaces near, generating new regimes of the visible, the invisible, and the camouflaged.

When studying (in)security, then, space must be understood in multidimensional ways even if anthropologists are rightly critical of the often-poor information, the absence of evidence, or the many other gaps and fissures in securityscapes. Security and risk maps, like the ones Andersson shows us, often purport to be dynamic or even real-time maps, but they are often little more than representations of historical data layered with media updates and forecasting. That said, some security consultancies distance themselves from their own predictions, such as the Security Analysis and Research Consultancy's recent report on Nigeria, which admitted the difficulties in forecasting due to "underlying elements" such as "social injustice." But again we must think in spatiotemporal terms, and once more the Vietnam wars are illustrative of earlier virtualization experiments: recall US Secretary of Defense Robert McNamara's efforts to visualize and then violently disrupt the Ho Chi Minh trail with a wall of sensors connected to aircraft circling overhead, together with "antipersonnel" mines underfoot. Spaces of (in)security have long been dynamic and multidimensional. Temporality is important here. 
The different vectors shown in "Here Be Dragons" are also fascinating and deserve more attention. Andersson does a wonderful job of using the concept of dangerization to connect different processes in the security-scape, from transformations in the institutional and sectoral division of labour to the bundling together of potential threats. Indeed, the negative publicity surrounding recent UN drone operations in Africa surely supports the case he makes. Of course, people in Mali experience this dangerization in specific ways, and Andersson's reflexive essay presents some of those experiences while attempting to say more. His fieldsite seems to vibrate and shift under foot. The speed of change is shocking, and now Mali is perceived, conceived, and lived in as an expanding arc of instability. But what of the spatiotemporal dimensions of dangerization within centers of security calculation? For European security experts, terrorism is approached in terms of specific spatiotemporal vectors. In short, experts see the future in Africa-Paris-style "marauding" attacks today, Westgate Mall or Ougadougou special forces-style attacks tomorrow. But the future is also very near. The vectors of socalled radicalization are one matter, but as the European Police Office recently warned, the threat is already here, with 5,000 "jihadists" and "home grown" threats inside fortress Europe. Simultaneously, this form of dangerization works off useless bimodal distributions and a very useful multidimensional and near-future security milieu. Danger, then, is not necessarily in the form of Boko Haram or al-Shabaab. Rather, Jacques Derrida's (1997:84) formulation seems more fitting, "a mobile multiplicity of potential interchangeable metonymic enemies, in secret alliance with one another: conjuration."

\section{Jeffrey A. Sluka}

Social Anthropology Program, Massey University, Palmerston North 4442, Aotearoa/New Zealand (j.sluka@massey.ac.nz). 31 V 16

While anthropology has always been, at least tangentially, interested in the topic of security, the anthropology of security is an emerging field that ties in with the parallel emergence of a new multidisciplinary "human security studies," because both focus on presenting critical, grounded, and local alternatives to the state-centered emphasis, in traditional security studies, on national security.

As Tessa Diphoorn has recently observed, security is a "hot topic" that is "indicative of a defining moment in late modernity" (2015), and the growing interest of anthropologists in this topic has been highlighted by Daniel Goldstein's call for a critical anthropology of security. Goldstein argues that "the world has entered a kind of 'security moment,' a new phase of global history characterized by increased surveillance of potential security threats, expansive government powers to investigate security breaches, armed intervention in places that supposedly foster terrorism, and restriction on individual freedoms in the name of protecting personal and national security" (2010:487).

The promise or opportunity for the discipline in this area is the critically engaged research Goldstein calls for, which explores and elucidates the "important relationships between security discourse and practice, human and civil rights, and the entailments of neoliberalism by offering a perspective on these issues which is at once ethnographically sensitive and attuned to contemporary global interconnections" (2010:487). In particular, anthropology is well placed to contribute important analyses of the security apparatus, its politics and supporting ideology, and its impacts on local communities. This article by Ruben Andersson is an excellent example of how this promise is now coming to fruition.

Andersson also illustrates the significant threats of working in this field. Beyond the obvious existential ones to personal health and safety (which I have written about managing or ameliorating; see Sluka 1990, 1995, 2012, 2015), the most significant threat is the epistemological one represented by the fact that one of the freedoms under increasing restriction is academic freedom to conduct fieldwork, particularly "engaged anthropology," in an increasing number of "no-go zones"-locations officially defined as so dangerous and "insecure" as to require control over access to them by researchers and others (e.g., tourists). It is becoming increasingly difficult, in some cases now nearly impossible, to attain the growing number of ethical and other institutional approvals required to do such research.

This is amply illustrated by Andersson's case. He was required by his university to complete an extensive and detailed risk assessment, fill in multiple lengthy forms, attend security meetings, familiarize himself with safety procedures, engage with a private security contractor, and acquire expensive insurance. His experience with negotiating this process leads him to conclude that today "none but the most dedicated" should "even attempt" to conduct research in such "red zones" as Mali. This process presented him with an "anthropological dilemma at the edge of the danger zone," which he could only resolve by agreeing to severely restrict where he conducted his fieldwork, basically confining himself to the capital city of Bamako. That is, he was prevented from actually entering the rural areas in northern Mali where security is the most problematic and pressing issue.

Andersson admits that, to gain approval to conduct research in Mali, he basically had to decide to "stay away" from entering the country's rural "danger zone," which even he suspects may have represented a "cop-out." When he was compelled to do that, he was in effect imposing on his research the same "bunkering" he refers to as occurring with and limiting the success of state and international (e.g., UN) civil and military agencies, which he identifies as causing resentment, suspicion, and distrust - all of which are, of course, anathema to anthropological fieldwork.

The "interventionist dilemma" Andersson identifies state agencies as facing has a direct parallel with a serious emerging epis- 
temological and ethical "anthropological dilemma" in which our research must be increasingly managed at arm's length, because we are no longer permitted by the authorities to put our "boots on the ground" or risk "coming into harm's way," which leads to "ambivalent engagement and anxious withdrawal: stuck on the margins of danger zones, seeing them through the eyes of local helpers or the latest surveillance machinery. . . . Relationship by remote control." This disturbing development is evidence of a new politics of control that implies an involuntary return to the discredited early form of "veranda anthropology," most famously criticized by Malinowski, which effectively threatens a recolonization of the discipline.

Andersson observes that the putatively expanding fields of "global danger" are officially defined and restrictions on access to them are enforced by state institutions, universities, funding agencies, insurance companies, and other "powers that be." He insightfully notes that this definition of the red zones of the world is highly politicized, controversial, and often exaggerated. He is also correct to stress that this politically motivated "dangerization" process "has gone global in uncontrollable ways" and is ultimately not about security but rather "control."

Just as there is a popular (mis)conception that we live in a "postracial" era, there is a parallel belief that the contemporary age of economic or capitalist "globalization" is a postimperial one. While Andersson does pointedly refer to intervention, neoconservatism, global capitalism, and "security's broader 'colonization' of ever-larger parts of social life," he does not clearly identify that this is fundamentally related to ongoing imperialism. The impact of imperialism, the neverending and near-infinite source of resistance and conflict, is now being redefined as "insecurity." The forms, style, and mechanisms of imperialism have evolved from direct imperialism, to neoimperialism, then debt-leverage imperialism, and now what may be characterized as "security imperialism." Just as the old imperial mission was represented as "civilization," the new face of imperial intervention is disguised behind the mask of "security."

We should not be fooled. Is anyone naive enough to believe that the growth of securitization, the mass expansion of the state security complex, and the emerging global politics of security-for example, the massive expansion in recent years of the US Africa Command across the African subcontinentis really about helping, aiding, or assisting the peoples and nations of the region, or motivated by a desire to actually provide them with security? It is imperative that the phenomenon of security and securitization at both global and local levels must be read within an overtly neoconservative and neoimperial global geopolitics.

If we are to continue the honorable tradition in anthropology of critical anti-imperialism, we must energetically resist the forces that increasingly seek to compel us to "cop-out" of fieldwork in the increasing swathes of the planet officially defined as "no-go areas," "red zones," and "failed states." We cannot, as Andersson suggests, play the "trickster role" of "weaving back and forth between the inhabitants of the danger zone and the international interveners" if we cannot do fieldwork with those inhabitants and are once again confined to the "veranda."

\section{Bruce Whitehouse}

Department of Sociology and Anthropology, Lehigh University, 31 Williams Drive, Bethlehem, Pennsylvania 18015, USA (brw208@lehigh.edu).17 III 16

As a Mali specialist, I am forced, in a wrenchingly personal sense, to confront the problems of risk and distance described here. My desire to become an anthropologist was sparked during Peace Corps service in Mali from 1997 to 2000; I conducted my first ethnographic fieldwork in Mali in 2002, returning every two to three years thereafter to renew friendships and undertake new research. I was there as the country plunged from "donor darling" to "failed state" over the first 6 months of 2012.12 The gravity of the country's crisis only truly dawned on me in early April of that year, when Peace Corps Mali evacuated its volunteers, something unprecedented in its 41-year existence, despite major famines in the 1970s and 1980s and political unrest and a military coup in the early 1990s.

Before 2012, like many others, I had seen Mali as a fundamentally stable, safe place to live and work, unlike Liberia, Congo, or other "basket cases." Its people were known for their friendliness and vibrant artistic scene. For years, Malian authorities capitalized on their country's positive image abroad to attract revenue from tourism, cultural festivals and exchanges, and foreign investment. With the benefit of hindsight, we see that this image was generated only by papering over deep divisions within Malian society including, but by no means limited to, intergroup tensions in the country's northern regions.

Today the Malian state is on UN life support. As Andersson observes, Mali's people are on edge, increasingly wary of the "international community" in general and its presence in their country. And Mali is by no means unique in the region for its newly "dangerized" image: since the time I served in the Peace Corps, that organization has pulled its volunteers out of half a dozen West African countries amid risks posed by political violence and the Ebola virus. A few months after restarting its Mali program in mid-2015 (albeit on a limited scale and far from the country's northern "red zones"), the Peace Corps shut it down again in the wake of an attack on Bamako's Radisson hotel during which Islamist militants killed 20 civilians (one American, two Belgians, three Chinese, one Israeli, six Malians, six Russians, and one Senegalese). Mali and much of West Africa are now effectively off limits for most citizens of wealthy countries.

12. See Whitehouse (2012) for a brief review of those events. 
The proliferation of "no-go areas" in Africa and beyond imposes heavy costs, not just on those areas' inhabitants but also on anthropology and any other field in which analysis requires and valorizes local knowledge. Many of my fellow Africanist scholars in the United States got their start working on the continent for the Peace Corps or NGOs at the community level. Most American social scientists I meet who have worked in Guinea, Mauritania, or the Central African Republic also began on that professional track. Today, however, it is exceedingly difficult if not impossible for young North Americans or Europeans to acquire first-hand experience of everyday life in places like these. Recent terrorist attacks in Burkina Faso and Côte d'Ivoire have added those countries to the high-risk category. Western government agencies are reluctant to send their staff to such places, and research grants will no longer underwrite fieldwork there. In the years ahead, the ongoing mapping of security threats and the process of "risk transfer" Andersson describes will dramatically reduce the capacity of outsiders (and not just Westerners) to understand societies and peoples of the Sahel, central Africa, or other "hot spots" in emic terms.

The instrumentalization of real and perceived risk by African elites and ordinary citizens alike, whether concerning terrorism, migration, or environmental destruction, fits into longstanding strategies of extraversion on the continent (Bayart 2000). Yet leveraging risk seems like an increasingly attractive option in Africa these days. Given a choice between remaining loyal to the existing political system, voicing critiques of that system, or exiting it altogether (to use Hirschman's [1970] terminology), subjects of contemporary African regimes may see few incentives for loyalty and no space for productive nonviolent critique. As Malians followed the progress of 2015 negotiations to resolve their country's latest Tuareg rebellion against the central government-negotiations in which donor governments played an active role-many who felt their loyalty had gone unrewarded asked whether taking up arms against the state was their best hope of making their voices heard. Seeking benefits by posing a danger to the state and/or to regional security seems to pay the greatest dividends; as Djibril put it to Andersson, "In order to be rich, you have to threaten." Provided, that is, one does not adopt the language of Islamism to make those threats; doing so could make one the target of a French air strike. In the current post-Cold War, postcolonial order, some threats may be bargained with, others must simply be eliminated.

Meanwhile, many of Africa's young men and a growing number of its young women see the option of exit through emigration as their most likely route to economic and personal self-fulfillment. The consensus linking migration to poverty noted by Andersson among officials and would-be migrants, however, ignores an inconvenient fact: the world's poorest countries tend to produce more international migrants, not fewer, as their economies develop (Flahaux and de Haas 2016). If the migration of Africans poses a problem to African and Western governments, it is a problem with no easy fixes.
I cannot compare the uncertain future of Africa's frustrated youth (Honwana 2012) to the uncertainty faced by those of us in the West who have built careers on specialized knowledge of places now considered no-go areas. I continue to hope that Mali will one day soon have cause to be decategorized as an exporter of danger. In the meantime, though, Andersson's work offers valuable insight into the role of the anthropologist in the danger zone.

\section{Reply}

Before I set off for Bamako in 2014, a formerly Mali-deployed European military officer advised me to book into the city's Radisson: "It's the only hotel with armed guards." In the autumn of 2015, it was that very hotel that jihadists chose as their high-profile target in a complex attack of the kind later to be replicated in Burkina Faso and Ivory Coast. As a result, the interveners' bunker mentality was yet again reinforced in Bamako, while attacks on peacekeepers tragically kept coming thick and fast in Mali's north. In those days, one frustrated Bamako-based aid worker told me that the problem with Mali was that "the threat is everywhere, everybody, at any time."

I bring up these incidents to make clear that the dangers lurking in faraway places are not mere abstractions, as Nicholas Farrelly suggests a reader of "Here Be Dragons" may infer. They are certainly real enough. Nor does finicky risk management, for all its problems, always serve as crude access control of the kind Jeffrey Sluka criticizes in his important defense of engaged anthropology in risky areas. Unlike the journalists prevented from entering northern Mali during France's Operation Serval "for their own safety" while French soldiers filmed their own redacted war, I could theoretically have headed to the no-go north - at my own risk. As I wrote, "my apprehensions cannot be blamed on institutional straightjackets alone." I believe the same goes for many other researchers and workers deployed to crisis areas: we bemoan the restrictions, yet more often than not abide by them, or simply stay away. It is easier that way, especially since it seems so hard to control, assess, and quantify distant dangers - that is, to turn them into calculable risk-and since full liability shifts onto us as soon as we stray from supposed safety.

There is much work to be done on the practical, political, and ethical dimensions of access here. Anthropologists working on risky areas can, for instance, reveal how strict security protocols may principally serve to "cover the asses" of the higher-ups, to cite one angry European official reflecting to me on his fruitless, fortified deployment into conflict-hit Libya. We may also show how such protocols often generate insurmountable distance from local society while proposing muchneeded alternatives of the kind that several of the insightful 
commentators on "Here Be Dragons" have themselves provided over the years. However, what I principally sought to shine a light on in my piece was a broader anthropological line of inquiry stemming from that initial methodological conundrum, namely: what kind of world emerges from attempts to keep danger at bay-contained, calculated, and controlled-precisely at the moment when "danger itself" is running wild and free, systemic rather than strictly locality bound? How are world-ordering and world-disordering knowledges, practices, and mechanisms focused on fear and danger shaping not just the physical and social terrain (to use military terminology) but also the mental one, on which so many of today's horrific battles are fought? On what historical legacies is this peculiar landscape of intervention built, and what relationships between Self and Other are being forged upon it?

From a historical viewpoint, there is indeed something rather old-fashioned afoot in my piece, as Farrelly notes. That is so for an empirical reason: today's large-scale international interventions rehearse those of earlier eras. The "dragons" of our maps may be globally spread, but not evenly so. It is the old colonial and imperial powers of the West that invest most in both conjuring them and keeping them at bay and which, moreover, have the firepower and global projection needed to do so. In Mali, the Chinese have provided a peacekeeping contingent, but their principal interest (as Farrelly notes more broadly) is resources and markets. That generates its own problems, but much less so than framing the relation to the Sahel in terms of danger, as Western powers are increasingly doing. As Sluka notes, we are facing a geopolitical moment in which "security" may motivate multifarious interventions across diverse societies folded into US "homeland security" or European border strategies.

In investigating this mapping and management of risk and danger, we may start, along with Mark Maguire, with the conjoined spatial and temporal stakes at work. In the fortified Kabul of 2016, to skip across the "arc of instability," the daily rhythms of expatriates take on shifting hues of risk. Official restrictions on movement stretch, in the terminology, from "green city" - traveling between safe destinations allowedto "white city," or lockdown. And lockdown is increasingly what life is about for civilian expats, while US officers roar past in helicopters shuttling them safely from airbase to headquarters.

While maps of red, black, and green zones provide deceptively neat two-dimensional renderings of risk, danger and "distanciation" rather play out over four sprawling dimensions: horizontally, vertically, and temporally. I trace these dimensions in my larger project (Andersson, forthcoming), but suffice it to say here that today's warriors and interveners are themselves very much aware of the complex spatialtemporal stakes involved. For instance, drone operators refer to the "soda straw effect," a metaphor that acknowledges the vastly reduced understanding of the world below, seen in little round glimpses afforded by the burning eye in the sky. The soda straw metaphor moreover frames our interests in that world in terms of stealthily suctioning out as much intelligence as possible, generating, in Maguire's words, "new regimes of the visible, the invisible, and the camouflaged."

The soda straw effect echoes what Weizman (2007), in his study of shifting Israeli strategy in Gaza, calls a "politics of verticality." On the basis of this vertical dimension, it is tempting to go along with critical writers on drone warfare and flesh out ethnographically what Shaw (2013) has termed "predator empire" - or US biopolitical targeting of "dangerous life patterns" over an ever-extending battle space of "kill boxes" and "mowed lawns," to cite the virtual warriors' jargon. Yet while such critical perspectives are important, there are reasons why I steer away from the imperial terminology suggested by Sluka. The foremost is the risk Maguire identifies in deploying potentially "all-explaining concepts" when facing a distinct configuration of power. In fact, this is precisely why I rather find it useful to globalize the term "dangerization" as it links up small-scale internal security fields with "external" ones. Rather than offering "premature classification," it can serve as a tool and a torch that helps cast a different light on deeper trends that may not fully (or not only) fit into the frame of empire.

As we shine such a flickering light into the global margins, the productivity of these should strike us. As Farrelly notes, full control is by no means necessary in the unruly "global Zomia(s)" of today. Rather, distant disorder may be productive and profitable in its very unruliness. To find an analytical language for this productivity, I briefly suggested building on Saskia Sassen's insights into intensified trends of capitalist value extraction combined with a productive take on the value of global risk itself. Through this lens, seemingly remote zones look rather central to a new world disorder in which they serve as a convenient stage for geopolitical battles, for struggles over illicit cross-border flows, and for media-fuelled propaganda wars, as seen from the Afghan-Pakistan borderlands to the Sahara. While these examples remain Western-centric, I insist that "Here Be Dragons" simply provides a rough road map for a fuller global investigation of the political economies and geographies of danger, focused perhaps most fruitfully on the novel frontiers of value extraction and risk taking in evidence in such disparate areas as "old Zomia," the Sahel/Sahara, and the Amazon.

Amid the proliferation of threats and opportunities, containment emerges as a key objective, especially in the Westerndesignated arc of instability. Yet efforts to isolate and block perceived threats while transferring them to an "elsewhere" is a fraught prospect, as danger proliferates in nonlinear ways outside "kill boxes" or red zones of risk.

One fruitful way for anthropologists to approach this mess (and complement the vast literature from other disciplinary perspectives) is via the relationships forged through containment. Take AMISOM, the African Union "peace operation" (or, more accurately, counterterror campaign) in Somalia, which has seen countless deaths of EU-paid and UN-equipped African soldiers over its faltering decade-long existence. "We are 
willing to pay. We pay with blood, you pay us the cash. If you provide the cash, we provide the bodies. That is the balance." This was how one Kenyan colonel put the deal to me amid anger at an EU paycut for troop-contributing states in 2016. While the risk hierarchies pinpointed in my article were very clear to the colonel, he also insisted that Somalia was principally a theatre for global dangers abetted by Western interveners themselves. As he put it, echoing Malian military officers in Bamako: "Somalia's not a regional problem. The reason why the EU is funding is because they want the problem to be contained in Africa. They don't want . . . large masses of Somalis knocking at the door of Europe trying to seek refugee status." Without fresh funding, he concluded, "it will be difficult to sustain operations, and it may reach a level where regional states begin to say, 'We pull back to our borders.'”

In short, containment strategies rarely if ever contain systemic risks. This includes, inter alia, the problems generated when outsourced partners start "leveraging risk," to cite Bruce Whitehouse: AMISOM troop contributors have become dependent on the mission to fund and keep busy their ailing armies. It also includes the "multidimensional" threats Maguire refers to, which are of course upmost on Western security experts' minds. As one European peacekeeper put it to me, the "enemy" back in his home capital was more well prepared and dangerous than the one in Mali's north. Yet while politicians focus on limiting risk exposure to soldiers in the field, terror attacks on soft targets keep escalating, generating distressing new risk hierarchies and risk transfers both outside and within "the West" itself.

If containing danger geographically remains a dangerous fantasy, the mental terrain of danger likewise feeds excess and perpetuation. In 1994, setting the stage for our fearful present, Rwandan fighters killed and mutilated 10 Belgian troops, swiftly triggering the withdrawal of their contingent-at the core of the UN mission - and so paving the way for the genocide. Later a senior Rwandan official said, "We watch CNN too, you know.” As Kofi Annan (Annan and Mousavizadeh 2012: 57) noted, "He was referring to the lesson that they had garnered from Somalia the year before [in the "Black Hawk Down" incident]: that the death of just a few foreign peacekeepers would be enough to end the appetite for intervention and allow them to get on with their murderous plans."

Nightmares, then, have an uncanny tendency to materialize, and no one knows this better than the social mediaattuned murderers of Daesh, as they use the withdrawal of large media organizations from the "danger zone" to their advantage in feeding stagings of Western fears into the atrocityhungry international news circuit. A gruesome video of early 2015, for instance, showed the brutal murder of 21 Egyptian Coptic Christians on a Libyan beach. The video may have been full of fakery but that mattered little as newscasts readily spread the murderers' propaganda around the world. In their clip, they cunningly staged the bundled fears of mass migration, conflict, and terrorism to Western audiences, sullying that perfect medium - the turquoise Mediterranean waters,
Europe's deep grave and barrier - with the encroaching reds of danger.

Anthropologists have plenty of tools in our inherited analytical kit to study these fraught borderlines between safety and danger, between self and "absolute Other," but to return to my opening lines, our practical preparation is rather more scant. Körling, along with Sluka, expresses rightful concern over our disciplinary relevance if we cannot access local inhabitants, while Whitehouse takes this further by noting that a wider risk-averse retreat reduces chances to obtain formative experiences of other places and cultures, and so limits future connections of a deeper kind, including anthropological ones.

We must find ways of bridging these divides. We need more frank discussion among anthropologists of the options at hand and the limits of our reach. In this, we can learn from aid workers, journalists, peacekeepers, and locals who have braved the front lines, while building further on my commenters' own insightful interventions into ethnography "among the dragons."

In my project, instead of bridging the divide, I rather take that divide itself as the object of inquiry. My starting point is the anthropological frontier zone where our traditional methods reach their point of near impossibility. Participantobservation may here be not just a fundamental part of anthropology's "educational" ethos, in Ingold's (2014) holistic sense, but also function as a tool for "testing the waters." How far does it reach, and what does this limit tell us?

In the world's growing resistance to our methods, we may come to see ourselves as bit players in a larger historical drama that harks back to the days of veranda anthropologists and precolonial explorers. While we should be cognizant of the risk of disciplinary "recolonization," as Sluka puts it, there is one large difference this time round: our capacity to reach across scales and frames of analysis, developed over decades of anthropological critique. Building on this, we should certainly persevere in gaining access to societies on the "margins," yet we also need to do more. Among other things, we can turn the making and makers of those margins into our object of study, and so straddle - in whatever way we can, by whichever means are at hand - the borderlands of globalized danger.

—Ruben Andersson

\section{References Cited}

Andersson, Ruben. Forthcoming. The danger zone: our global map of fearand how to redraw it. Oakland: University of California Press.

Andersson, Ruben, and Florian Weigand. 2015. Intervention at risk: the vicious cycle of distance and danger in Mali and Afghanistan. Journal of Intervention and Statebuilding 9(4):519-541.

Annan, Kofi, and Nader Mousavizadeh. 2012. Interventions: $a$ life in war and peace. New York: Penguin.

Augé, Marc. 1995. Non-places: introduction to an anthropology of supermodernity. London: Verso.

Autesserre, Séverine. 2014. Peaceland: conflict resolution and the everyday politics of international intervention. Cambridge: Cambridge University Press. 
Ayson, Robert. 2007. The "arc of instability" and Australia's strategic policy. Australian Journal of International Affairs 61(2):215-231. [NF]

Barnett, Thomas P. M. 2004. The Pentagon's new map: war and peace in the twenty-first century. New York: Putnam.

Bayart, Jean-François. 2000. Africa in the world: a history of extraversion. African Affairs 99(395):217-267. [BMW]

BBC (British Broadcasting Corporation). 2014. France to 'deploy troops' to fight Sahara militants. BBC news, May 8. http://www.bbc.co.uk/news/world -africa-27327759 (accessed July 21, 2015)

Beck, Ulrich. 1999. World risk society. Cambridge: Polity.

Benmehdi, Hassan. 2014. Morocco, Mali to boost agricultural collaborationMagharebia. Morocco on the Move, April 25. http://moroccoonthemove.com /2014/04/25/morocco-mali-boost-agricultural-collaboration-magharebia /\#sthash.CUNiwNfL.dpbs (accessed July 21, 2015).

Bergamaschi, Isaline. 2014. The fall of a donor darling: the role of aid in Mali's crisis. Journal of Modern African Studies 52(3):347-378.

Besteman, Catherine. 1999. Unraveling Somalia: race, violence, and the legacy of slavery. Philadelphia: University of Pennsylvania Press.

Bierschenk, Thomas, Jean-Pierre Chauveau, and Jean-Pierre Olivier de Sardan, eds. 2000. Courtiers en développement: les villages africaines en quête des projets. Paris: Karthalav. [GK]

Bigo, Didier. 2014. Security: encounters, misunderstanding and possible collaborations. In The anthropology of security: perspectives from the frontline of policing, counter-terrorism and border control. M. Maguire, C. Frois, and N. Zurawski, eds. Pp. 189-205. London: Pluto.

Bolt, Neville. 2012. The violent image: insurgent propaganda and the new revolutionaries. London: Hurst.

Bourgois, Philippe I. 2003. In search of respect: selling crack in El Barrio. Cambridge: Cambridge University Press.

Burawoy, Michael. 2000. Global ethnography: forces, connections, and imaginations in a postmodern world. Berkeley: University of California Press.

Caillié, Réné. 1992 [1830]. Travels through Central Africa to Timbuctoo and across the great desert to Morocco, performed in the years 1824-1828. London: Darf.

Chandrasekaran, Rajiv. 2006. Imperial life in the emerald city: inside Baghdad's green zone. London: Bloomsbury.

Charbonneau, Bruno. 2015. The politics of peacekeeping interventions in Africa. International Peacekeeping 22(3):275-282.

Daniel, E. Valentine. 1996. Charred lullabies: chapters in an anthropography of violence. Princeton, NJ: Princeton University Press.

Derrida, Jacques. 1997. The politics of friendship. London: Verso. [MM]

Diphoorn, Tessa. 2015. Etnofoor call for papers: security. http://www.konflikt bearbeitung.net/en/meldungen/etnofoor-call-for-papers-security (accessed May 12, 2015). [JAS]

Duffield, Mark R. 2001. Global governance and the new wars: the merging of development and security. New York: Zed.

- 2010. Risk-management and the fortified aid compound: everyday life in post-interventionary society. 4(4):453-474.

FAC (Foreign Affairs Committee). 2014. The UK's response to extremism and instability in North and West Africa. House of Commons report, March 21.

Farrelly, Nicholas. 2012. Ceasing ceasefire: Kachin politics after the stalemates. In Myanmar's transition: openings, obstacles and opportunity. Trevor Wilson, Monique Skidmore and Nick Cheesman, eds. Pp. 52-71. Singapore ISEAS. [NF]

2013. Nodes of control in the Indo-Burmese borderlands. In Borderland lives in Northern South Asia. David Gellner, ed. Pp. 194-213. Durham, NC: Duke University Press. [NF]

Fassin, Didier. 2011. Policing borders, producing boundaries: the governmentality of immigration in dark times. Annual Review of Anthropology 40: 213-226.

2013. Enforcing order: an ethnography of urban policing. Oxford: Polity.

Fast, Larissa. 2014. Aid in danger: the perils and promise of humanitarianism. Philadelphia: University of Pennsylvania Press.

Feldman, Allen. 1991. Formations of violence. Chicago: University of Chicago Press.

Feldman, Gregory. 2012. The migration apparatus: security, labor, and policymaking in the European Union. Stanford, CA: Stanford University Press.

Flahaux, Marie-Laurence, and Hein de Haas. 2016. African migration: trends, patterns, drivers. Comparative Migration Studies 4(1):1-25. [BMW]

Forsyth, James. 2014. Michael Fallon: parliament needs the 'courage' to vote for war. Spectator, September 27. http://www.spectator.co.uk/features/9322432 /we-shouldnt-be-ambiguous/ (accessed July 21, 2015).
Gettleman, Jeffrey. 2015. A catch-22 in Kenya: Western terrorism alerts may fuel terrorism. New York Times, February 23. http://www.nytimes.com/2015 /02/24/world/africa/as-tourism-sags-on-kenyan-coast-terrorists-could-lure -the-unemployed.html?_r $=0$ (accessed July 21, 2015).

Goldstein, Daniel M. 2010. Toward a critical anthropology of security. Current Anthropology 51(4):487-517.

Greene, Graham. 1955. The quiet American. London: Heinemann. [MM]

Gregory, Derek. 2011. The everywhere war. Geographical Journal 177(3):238250.

Grierson, Jamie, and Rowena Mason. 2015. Tunisia and Britain in diplomatic row as UK tourists fly home. Guardian, July 10. https://www.theguardian .com/world/2015/jul/10/uk-tourists-fly-home-tunisia-criticises-travel-advice -sousse (accessed July 21, 2015).

Guichaoua, Yvan. 2013. Mali: the fallacy of ungoverned spaces. University of East Anglia Development blog, February 12. https://www.uea.ac.uk/inter national-development/dev-blog/home/-/asset_publisher/1I1JoAAhCZsR /blog/id/2506832 (accessed July 21, 2015).

Gupta, Akhil. 2015. Is poverty a global security threat? In Territories of Poverty. A. Roy and E. Shaw Crane, eds. Athens: University of Georgia Press.

Gusterson, Hugh. 1997. Studying up revisited. Political and Legal Anthropology Review 20(1):114-119.

. 2004. People of the bomb: portraits of America's nuclear complex. Minneapolis: University of Minnesota Press.

Hagberg, Sten, and Gabriella Körling. 2014. Inaccessible fields: doing anthropology in the Malian political turmoil. Anthropologie et Développement 40-41:145-161. [GK]

Hannerz, Ulf. 2003. Being there . . . and there . . . and there! reflections on multi-sited ethnography. Ethnography 4(2):201-216.

Harms, Erik, Shafqat Hussain, and Sara Shneiderman. 2014. Remote and edgy: new takes on old anthropological themes. HAU: Journal of Ethnographic Theory 4(1):361-381.

Hirschman, Albert O. 1970. Exit, voice, and loyalty: responses to decline in firms, organizations, and states. Cambridge, MA: Harvard University Press. [BMW]

Honwanda, Alcinda. 2012. The time of youth: work, social change, and politics in Africa. Boulder, CO: Rienner. [BMW]

Ingold, Tim. 2014. That's enough about ethnography! HAU: Lournal of Ethnographic Theory 4(1):383-395.

Kaplan, Robert D. 1994. The coming anarchy: how scarcity, crime, overpopulation, tribalism, and disease are rapidly destroying the social fabric of our planet. Atlantic February. http://www.theatlantic.com/magazine/archive /1994/02/the-coming-anarchy/304670/.

Keen, David. 2012. Useful enemies: when waging wars is more important than winning them. New Haven, CT: Yale University Press.

Körling, Gabriella, and Sten Hagberg. 2014. Inaccessible fields: doing anthropology in the Malian political turmoil. Anthropologie et Développement 40-41:143-157.

Kovats-Bernat, J. Christopher. 2002. Negotiating dangerous fields: pragmatic strategies for fieldwork amid violence and terror. American Anthropologist 104(1):208-222.

Leach, E. R. 1954. Political systems of highland Burma: a study of Kachin social structure. Cambridge, MA: Harvard University Press. [NF]

Lianos, Michalis, and Mary Douglas. 2000. Dangerization and the end of deviance. In Criminology and social theory. D. Garland and R. Sparks, eds. Oxford: Oxford University Press.

Lutz, Catherine A. 2001. Homefront: a military city and the American twentieth century. Boston: Beacon.

Maguire, Mark, Catarina Frois, and Nils Zurawski. 2014. The anthropology of security: perspectives from the frontline of policing, counter-terrorism and border control. London: Pluto.

Malkki, Liisa H. 1997. News and culture: transitory phenomena and the fieldwork tradition. In Anthropological locations: boundaries and grounds of a field science. A. Gupta and J. Ferguson, eds. Pp. 86-101. Berkeley: University of California Press.

Masco, Joseph. 2014. The theater of operations: national security affect from the Cold War to the war on terror. Durham, NC: Duke University Press.

McDougall, James, and Judith Scheele. 2012. Saharan frontiers: space and mobility in northwest Africa. Bloomington: Indiana University Press.

Nay, Olivier. 2013. Fragile and failed states: critical perspectives on conceptual hybrids. International Political Science Review 34(3):326-341.

Nordstrom, Carolyn, and Antonius C. G. M. Robben, eds. 1996. Fieldwork under fire: contemporary studies of violence and survival. Berkeley: University of California Press. 
Piot, Charles. 1999. Remotely global: village modernity in West Africa. Chicago: University of Chicago Press.

Power, Matthew. 2013. Confessions of a drone warrior. GQ Magazine, October 23. http://www.gq.com/news-politics/big-issues/201311/drone-uav-pilot -assassination (accessed July 21, 2015).

Price, David H. 2011. Weaponizing anthropology: social science in service of the militarized state. Petrolia, CA: CounterPunch.

Pugh, Jonathan, Clive Gabay, and Alison J. Williams. 2013. Beyond the securitisation of development: the limits of intervention, developmentisation of security and repositioning of purpose in the UK Coalition Government's policy agenda. Geoforum 44:193-201.

Robben, Antonius C. G. M. 2010. Iraq at a distance: what anthropologists can teach us about the war. Philadelphia: University of Pennsylvania Press.

Russell, Bertrand. 1938. Power: a new social analysis. London: Allen and Unwin. $[\mathrm{MM}]$

Sassen, Saskia. 1991. The global city: New York, London, Tokyo. Princeton, NJ: Princeton University Press.

- 2014. Expulsions: brutality and complexity in the global economy. Cambridge, MA: Belknap/Harvard University Press.

Saxer, Martin. 2016. Pathways: a concept, field site and methodological approach to study remoteness and connectivity. Himalaya 36(2):104-119.

Scott, James C. 2009. The art of not being governed: an anarchist history of Upland Southeast Asia. New Haven, CT: Yale University Press. [NF]

Shaw, Ian G. R. 2013. Predator empire: the geopolitics of US drone warfare. Geopolitics 18(3):536-559.

Shaw, Martin. 2005. The new Western way of war: risk-transfer war and its crisis in Iraq. Cambridge: Polity.

Sluka, Jeffrey A. 1990. Participant-observation in violent social contexts: managing danger in fieldwork. Human Organization 49(2):114-126. [JAS]

- 1995. Reflections on managing danger in fieldwork: dangerous an thropology in Belfast. In Fieldwork under fire: contemporary studies of violence and survival. Carolyn Nordstrom and Antonius Robben, eds. Pp. 276294. Berkeley: University of California Press. [JAS]

. 2000. Death squad: the anthropology of state terror. Philadelphia: University of Pennsylvania Press.
2012. Staying alive while conducting primary research: fieldwork on political violence. In The Ashgate research companion to political violence. Marie Breen-Smyth, ed. Pp. 301-325. Farnham, UK: Ashgate. [JAS]

. 2015. Managing danger in fieldwork with perpetrators of political violence and state terror. Conflict and Society: Advances in Research 1(1):109124. [JAS]

Soares, Benjamin F. 2012. On the recent mess in Mali. Anthropology Today 28 (5):1-2.

Solomon, Hussein. 2013. Mali: West Africa's Afghanistan. RUSI Journal 158 (1):12-19.

Sriram, Chandra Lekha, ed. 2009. Surviving field research: working in violent and difficult situations. London: Routledge.

Tardy, Thierry, and Marco Wyss, eds. 2014. Peacekeeping in Africa: the evolving security architecture. London: Routledge.

Trouillot, Michel-Rolph. 2003. Global transformations: anthropology and the modern world. New York: Palgrave MacMillan.

Tsing, Anna L. 1993. In the realm of the diamond queen: marginality in an out-of-the-way place. Princeton, NJ: Princeton University Press.

Van Duzer, Chet. 2013. Hic sunt dracones: the geography and cartography of monsters. In The Ashgate research companion to monsters and the monstrous. A. Simon Mittman and P. Dendle, eds. Pp. 387-435. Farnham, UK: Ashgate.

van Schendel, Willem. 2002. Geographies of knowing, geographies of ignorance: jumping scale in Southeast Asia. Environment and Planning D: Society and Space 20(6):647-668. [NF]

Wallis, Joanne. 2012. The Pacific: from "arc of instability" to "arc of responsibility" and then to "arc of opportunity?" Security Challenges 8(4):1-12. [NF]

Weizman, Eyal. 2007. Hollow land: Israel's architecture of occupation. London: Verso.

Whitehead, Neil L., and Sverker Finnström. 2013. Virtual war and magical death: technologies and imaginaries for terror and killing. Durham, NC: Duke University Press.

Whitehouse, Bruce. 2012. What went wrong in Mali? London Review of Books 34(16):17-18. [BMW]

2013. What's to love about Mali? four things. http://bridgesfrombamako .com/2013/02/04/whats-to-love-about-mali/ (accessed July 21, 2015).

This content downloaded from 192.076.008.028 on November 15, 2016 12:05:27 PM 